\title{
Analysis and Survey the Position of Science and Technology in National Power
}

\section{ART ICLE INF O}

\section{Article Type}

Original Research

\section{Authors}

Mousavi Zare S.J. ${ }^{1} M A$

Zarghani S.H.* PhD,

Aazami H. ${ }^{2} P h D$
How to cite this article

Mousavi Zare S.J, Zarghani S.H, Aazami H. Analysis and Survey the Position of Science and Technology in National Power. Geographical Researches Quarterly Journal. 2018;33(3):88-105.

\section{A B S T R A C T}

Introduction and Background The national power of each country is rooted in a number of sources, which together form and interconnect the power of a country. Although, each dimension and component of national power has a separate and significant role in national power production, it seems that among the dimensions and components of national power, component of science and technology has a leading role. Accordingly, component of science and technology has a great influence in strengthening other dimensions of power, in addition to its significant and independent function.

Aims The aim of this paper is to analyse the position of science and technology in national power. This research aims to find out the impact and role of science and technology on other dimensions of national power like economic, political, and military dimensions.

Methodology This research is designed based on neoliberalism paradigm and secondary analysis methodology and also gathering opinions of domestic and foreign experts for purpose of constructing questionnaire.

Conclusion Findings shows that science and technology as an influential factor has a significant role in strengthening economic, military, political, cultural, geographical and social dimensions of power. Findings of fieldwork also show that science and technology component has a great influence on economic, military, political, cultural, social and geographical power respectively.

Keywords National Power; Science; Technology; Components of National Power

\section{I T A T I O N L I N K S}

[Ahmadi \& Ghaffarian; 2003] Principles of cognition ...; [Amjadi, et al.; 2012] Analysis the effect ...; [Asadi; 2013] The scientific wealth ...; [Bashiriyeh; 2000] Theories of culture ...; [Bellany \& Farhangh Kherad Mand; 1994] technology and military ...; [Davoodi; 2014] The Iranian science ...; [Deh Moobed, et al.; 2011] Exporting industries ...; [Dehghani Firoozabadi; 2015] Principles and ...; [Dick; 2003] The future of conflict ...; [Esudu; 2016] National power and ...; [Ezzati; 2012] The geostrategy and ...; [Faraji Rad \& Abdi; 2015] Scienctific and ...; [Gilpin; 2013] Global political ...; [Hafez Nia; 2011] Principles and ...; [Haj Fathaliha; 1993] Technology ...; [Heydari; 2010] Scientometrics: or the concept ...; [Hohn; 2011] Geopolitics and the ...; [Iran Technology Analysts Network; 2011] Conceptual survey ...; [Jablonsky; 1997] National power. US ...; [Jamshidi; 1995] Analysis and survey ...; [Kazemi; 2008] International relations ...; [King \& Larijani; 1996] Science and technology ...; [Kluz \& Firlej; 2015] The impact of ...; [Lall; 2000] Export Performance and ...; [Mahmoud zadeh, et al; 2017] The role and position of technology ...; [Mallik; 2016] Role of technology ...; [Mirzaei \& Abdi; 2003] Technology, concept ...; [Modares, et al; 2017] The role of military-industrial ...; [Mousavi Zare; 2017] The review and analysis ...; [National Research Council; 1999] The pervasive role ...; [National Research Council; 2009] 21st century innovation ...; [Nazari Zadeh, et al.; 2014] The role of individual factors in the success of ...; [Noroozi Chakoli; 2012] The role and situation ...; [Noroozi Chakoli, et al.; 2009] Assessment of science ...; [Nye; 2008] Power in the global ...; [Nye; 2010] Soft power: the means to success ...; [OECD; 1996] The knowledge-based ...; [OECD; 2002] Science, technology ...; [Oxford University; 1997] Oxford ..; [Partov; 2015] The crisis in ukraine ...; [Pillsbury; 2000] China debates the ...; [Quartz News Website; 2013] Why israel dominates ...; [RT News Website; 2014] All countries will ...; [Sadeghi \& Azarbayejani; 2006] Knowledge based economy ...; [Schiller; 1997] Mass communications and american ...; [SciDev News Website; 2009] Obama vows to boost ...; [Seyoum; 2004] The role of factor ...; [Shahnazi; 2013] Factors affecting ...; [Smith, et al.; 2013] International political economy ...; [Stockholm International Peace Research Institute; 2018] Trends in international ...; [Taleghani; 2005] The role of technology ...; [The guardian News Website; 2006] Pentagon's new weapon ...; [The guardian News Website; 2015] The numbers behind ...; [Turekian; 2016] The role of science diplomacy ...; [Valavi, et al.; 2011] Extraction of science ...; [Weiss; 2005] Science, technology and ...; [Zahedi \& Kheirandish; 2007] Explaining structural factors ...

\section{Article History}

Received: November 25, 2017

Accepted: October 7, 2018

ePublished: December 09, 2018

Copyright@ 2018. This open-access article is published under the terms of the Creative Commons Attribution-NonCommercial 4.0 International License which permits Share (copy and redistribute the material in any medium or format) and Adapt (remix, transform, and build upon the material) under the Attribution-NonCommercial terms. 


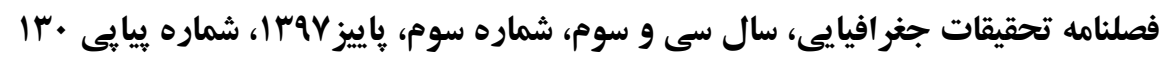

Mousavi Zare S.J. MA

Zarghani S.H. PhD

Aazami H. PhD

h-zarghani@um.ac.ir

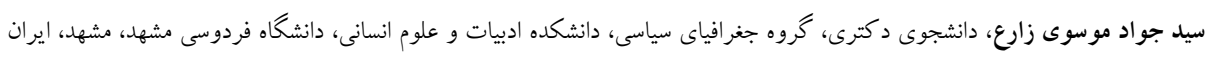

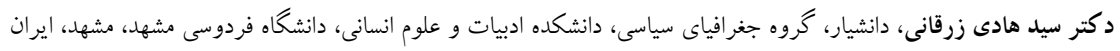

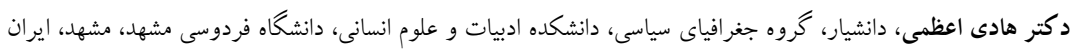

\title{
بررسى و تحليل جايكًاه علم و فن آورى در قدرت ملى
}

\author{
دريافت مقاله:M
}

DOI: $10.29252 /$ geores.33.3.88

جكيده

مقدمه: قدرت ملى هر كشور بركرفته از منابع متعددى است كه بهصورت همافزا و در بيوند با يكديكر، شاكله قدرت يكى

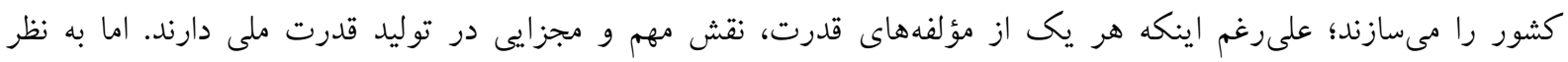

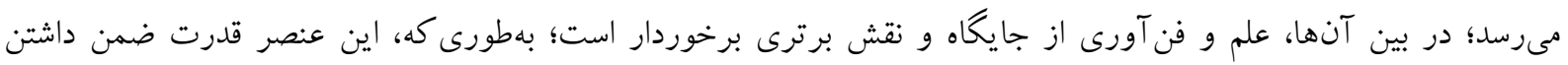
كار كرد مستقل، در تقويت ساير ابعاد قدرت ملى نيز مؤثر است.

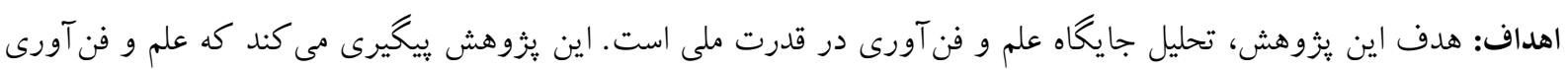

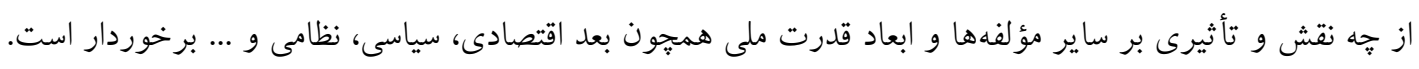

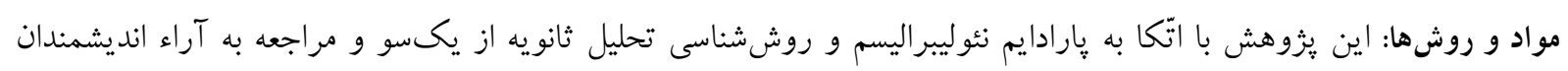
داخلى و خارجى در قالب يرسشنامه تنظيمشده است.

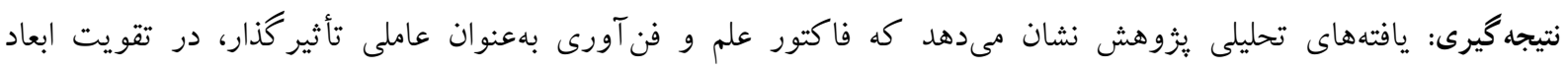

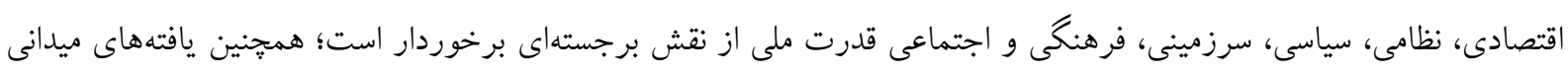

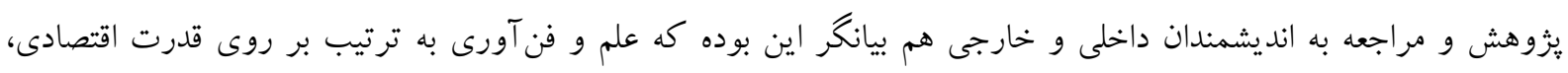

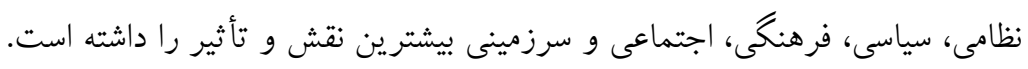

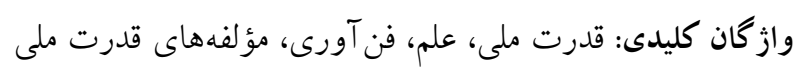

مقدمه

هر كشور در صلح، تعامل و تقابل نيازمند قدرتى است كه در يرتو آن از حقوق، منافع و پِرستيز بينالمللى خويش دفاع

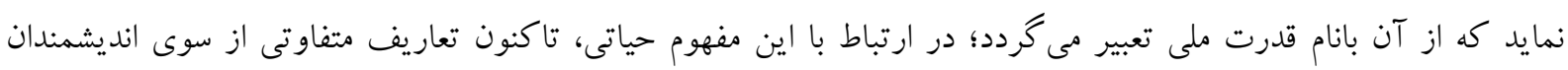

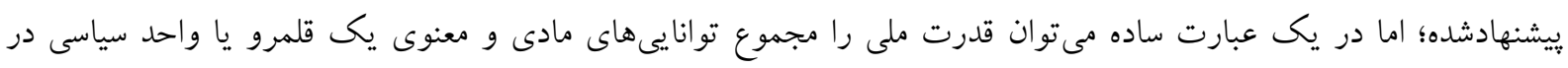

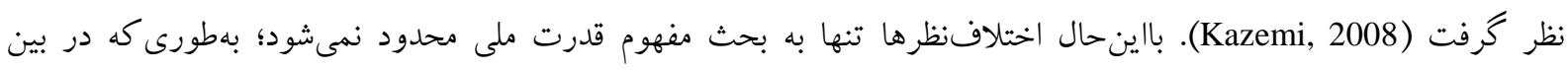

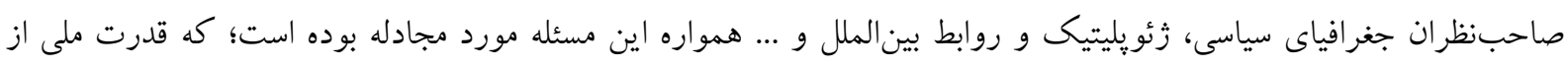

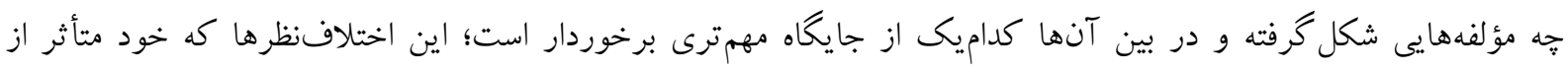

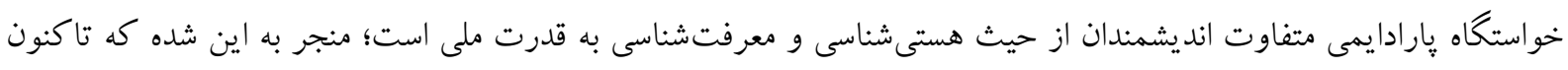

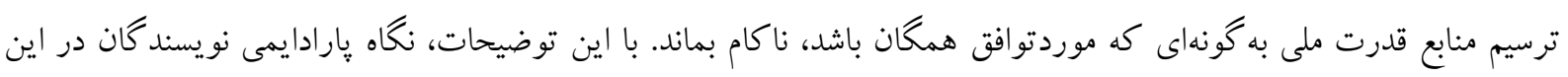




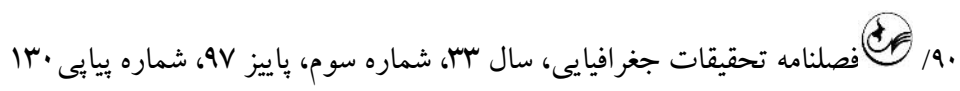

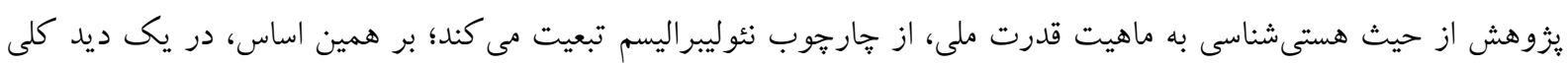

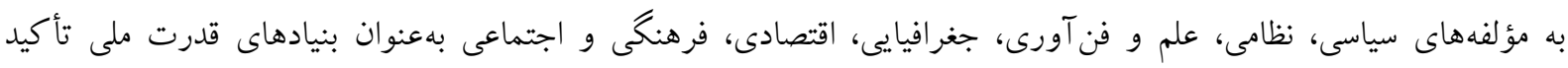

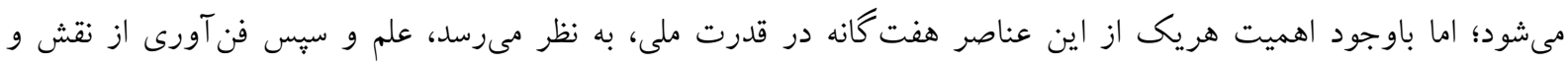

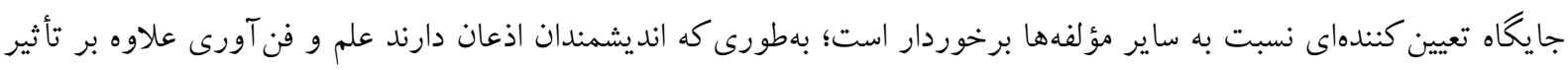

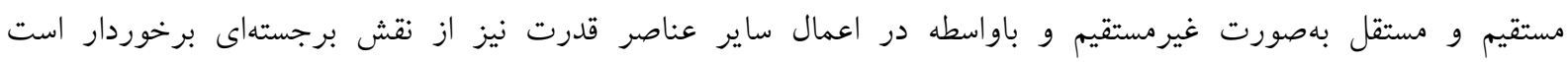

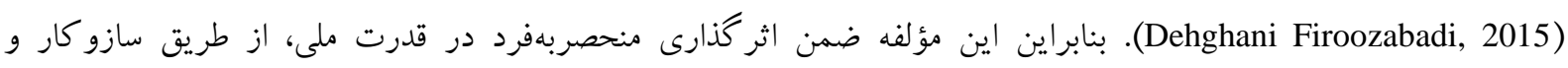

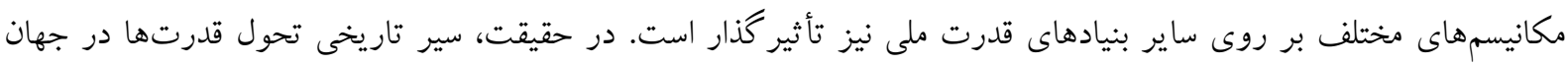

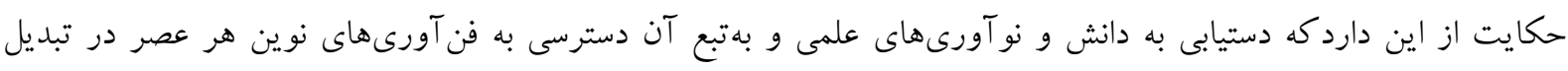

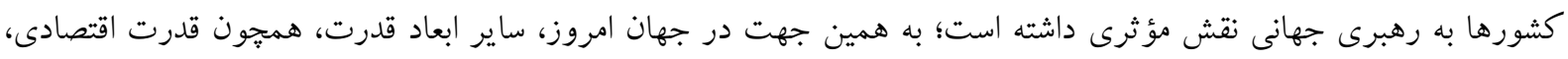

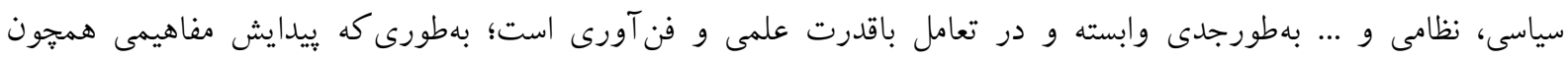

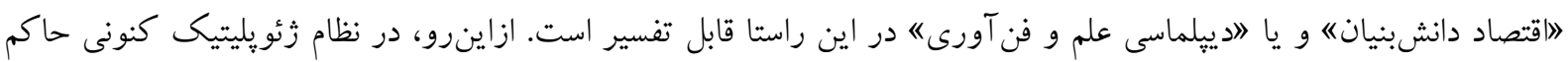

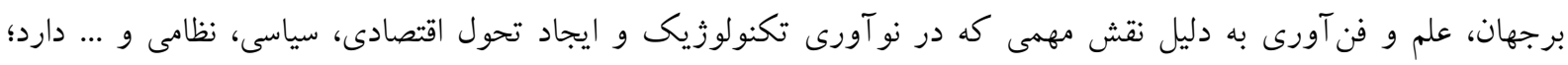

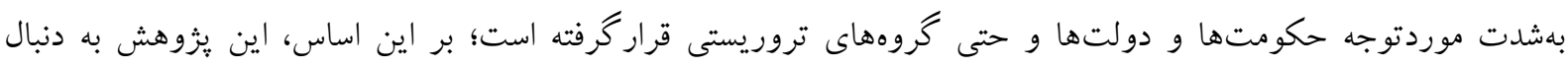

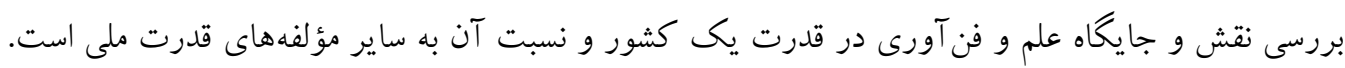

روش يزوهش

روش تحقيق اين يزوهش تحليل ثانويه مىباشد. سؤال اصلى يثوهش عبارت است از اين كه: علم فن آورى خه نقش و

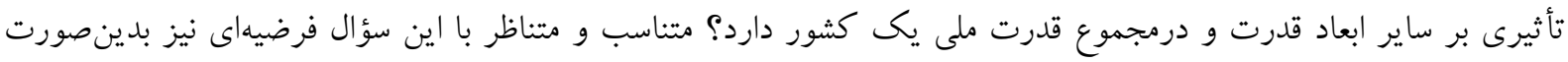

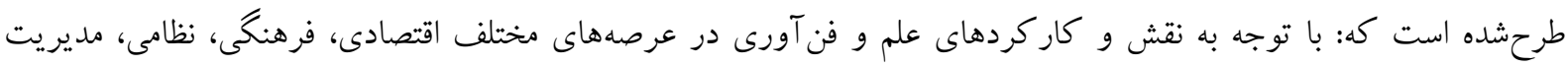

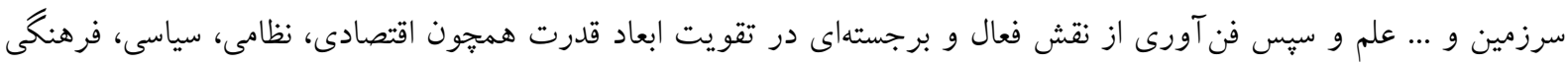

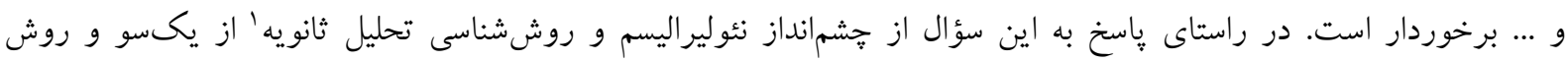

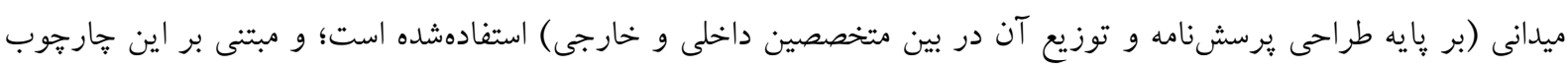

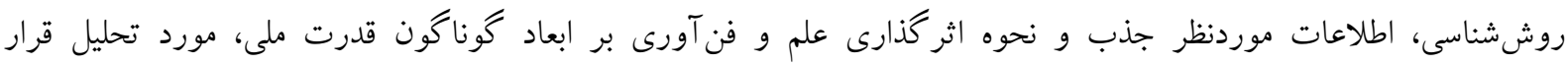
مى گيرد.

\section{مبانى نظرى}

ديد گاه نئوليبر اليسم در باب قدرت ملى

اگرجهه نئوليبراليسمها بهصورت شفاف عقايد خود را در مورد قدرت ملى بيان نكردهاند؛ اما مىتوان مبتنى بر آثار منتشرشده

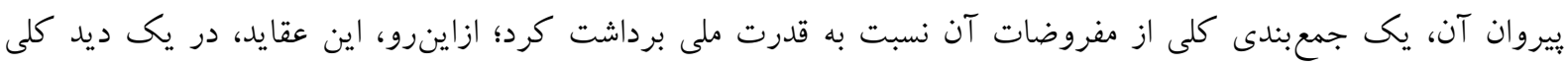
عبارتاند از: قدرت ملى علاوه بر جنبه عينى، از جنبه ادراكى و روانى برخوردار است (Dehghani Firoozabadi, 2015)

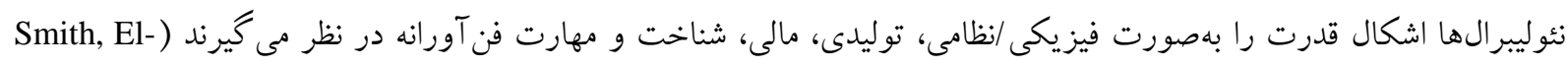

اين روش مبتنى بر تجزيه و تحليل دادهايى است كه در اصل توسط محققى ديگر و براى تحقيق متفاوتى ديخر گردآورى شده است ) Ahmadi \& Ghaffarian, 
(Anis, \& Farrands, 2013

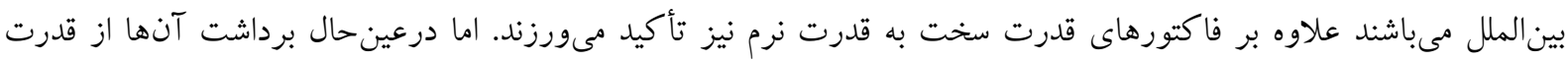

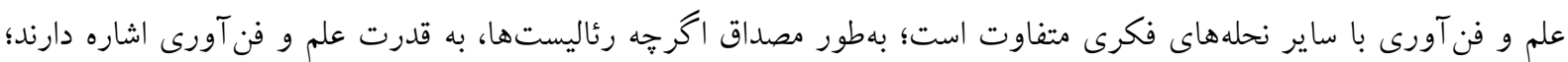

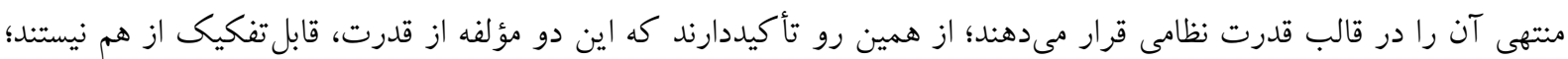

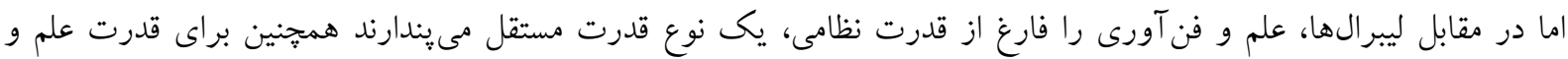

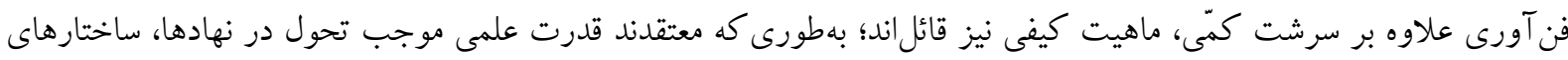

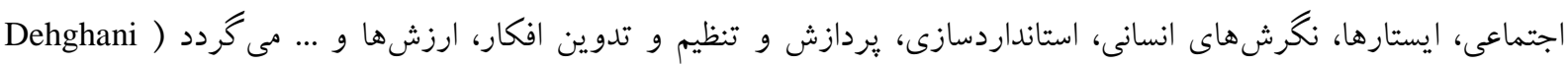

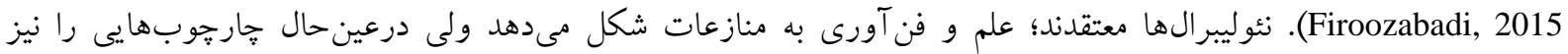
فراهم مىسازد كه مقدار زيادى همكارى در درون آنها انجام مى گيرد (Smith et al., 2013).

\section{مفهوم يابى قدرت ملى}

قدرت ملى همواره بهعنوان يك مفهوم جذاب و درعين حال مبهم توجه زيادى از انديشمندان را در حوزه جغرافياى سياسى و

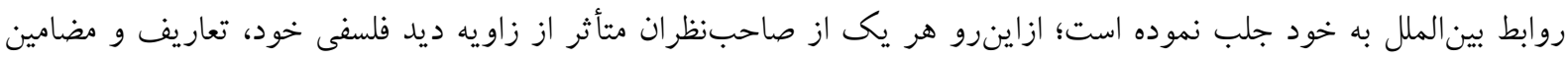

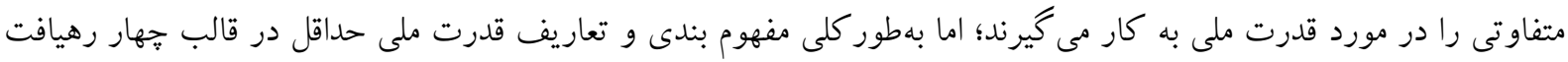
كلى قابل طبقهبندى مىباشد كه عبارتاند از: رهيافت اول: قدرت ملى بهمثابه كنترل منابع؛ مطابق با اين رهيافت قدرت ملى برحسب منابع و عناصر تشكيلدهندئده آن

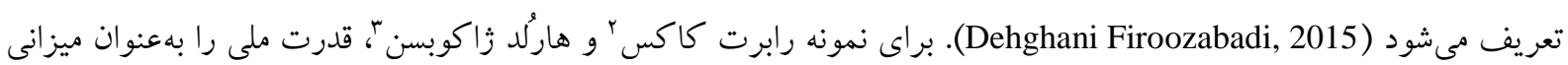

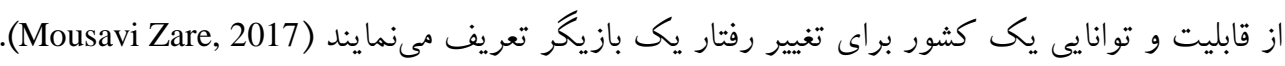

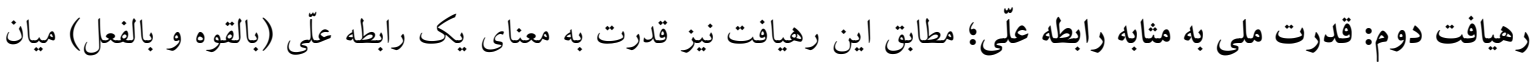

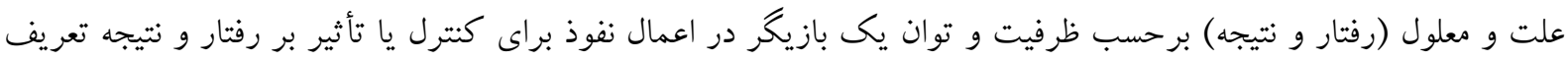

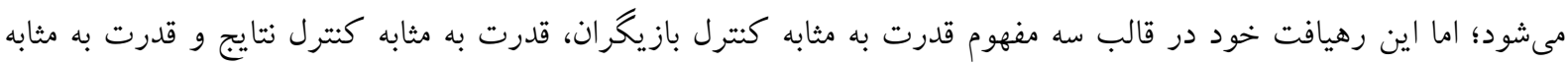

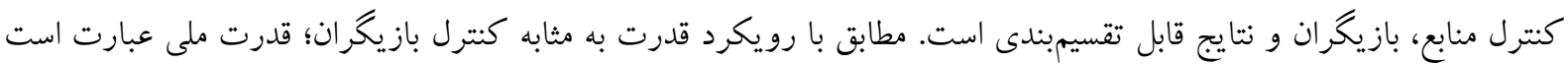

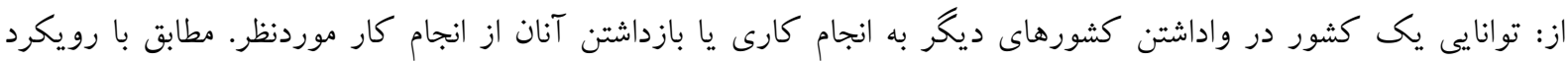

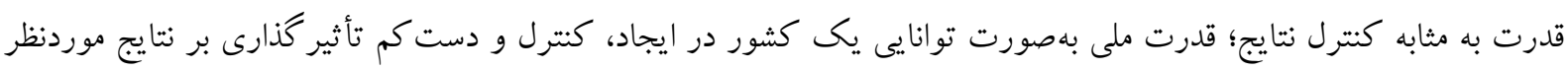

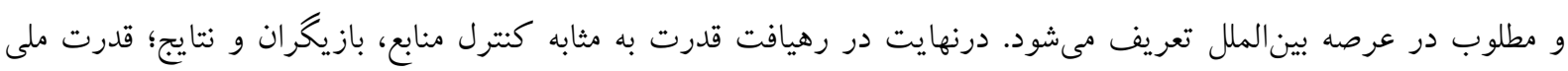

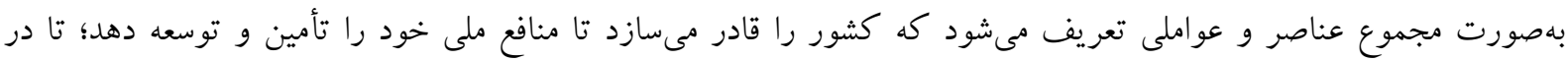

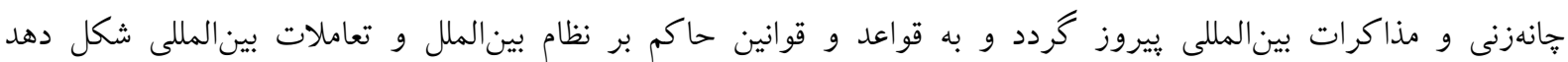

.(Dehghani Firoozabadi, 2015)

رهيافت سوم: قدرت ملى به مثابه روابط اجتماعى؛ مطابق با اين رويكرد، قدرت عبارت از تكوين و تأسيس سوزههاى

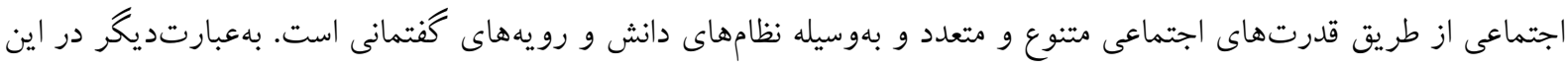

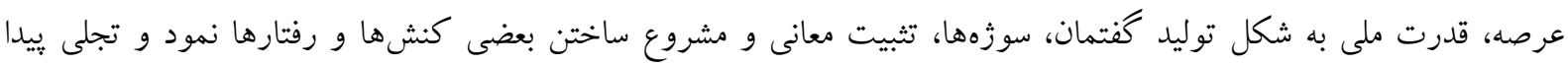
مى كند؛ مانند آفرينش سوزههايى خون كشور هاى توسعه يافته، تروريست، دمو كراتيك و .... (Dehghani Firoozabadi, 2015). 


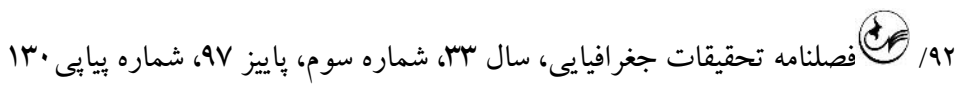
رهيافت جهارم: قدرت ملى به مثابه ساختار اجتماعى؛ مطابق با اين رهيافت قدرت ملى ناظر و معطوف به ساختارها، روابط

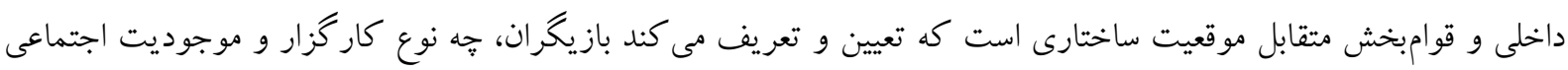

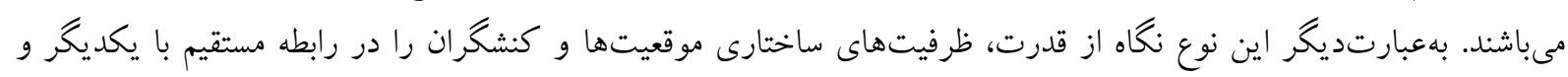

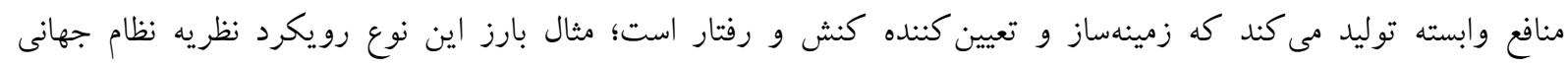

والرشتاين مىباشد (Dehghani Firoozabadi, 2015).

\section{مؤلفهاى قدرت ملى}

بهرغم مفاهيم و تعاريف مختلف از قدرت ملى؛ تعريف آن برحسب كنترل منابع همجنان در روابط بين الملل رايج و حتى

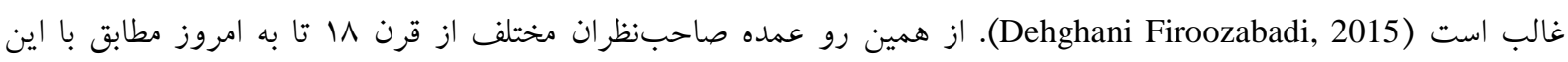

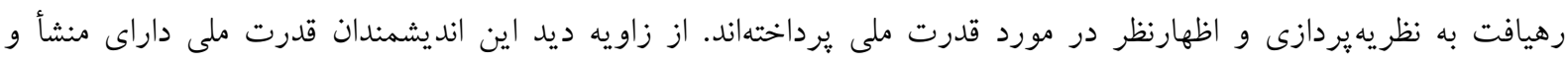

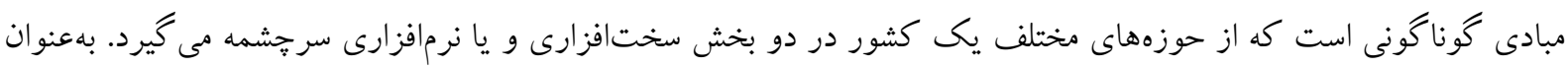

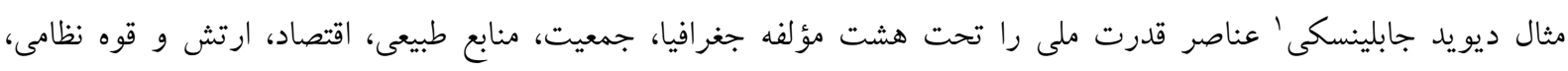

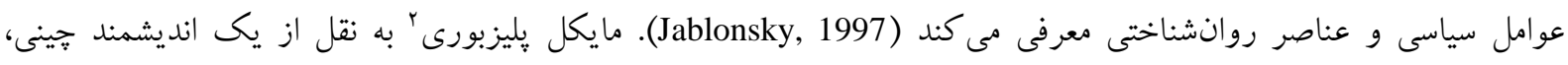

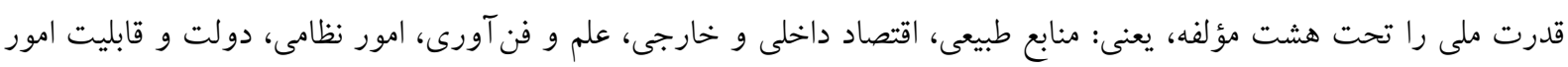

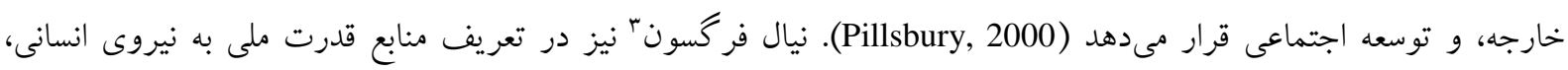

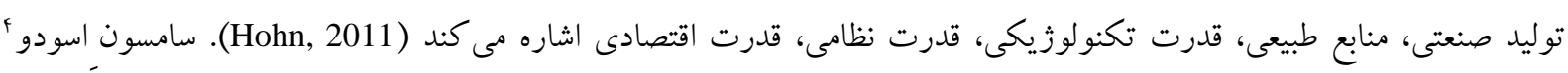

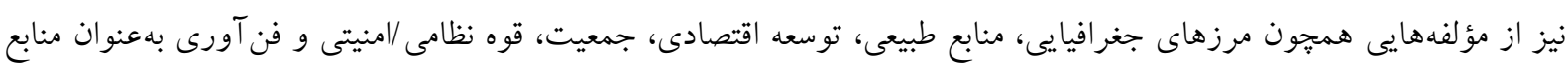

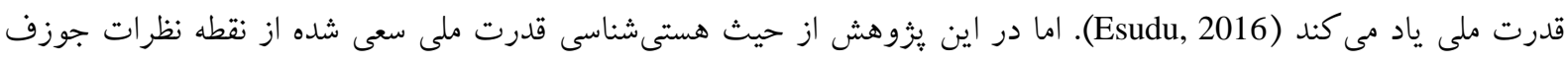

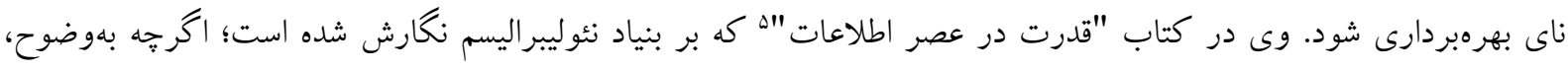

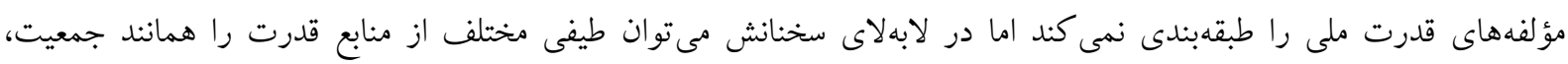

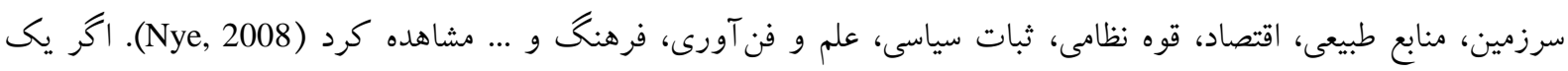

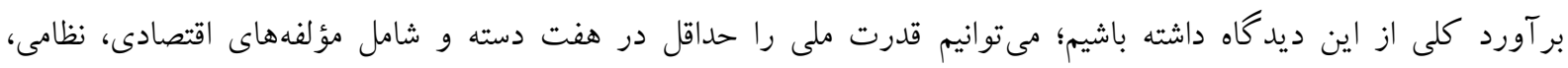

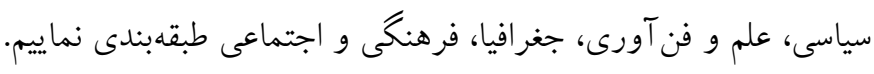
علم و فن آورى

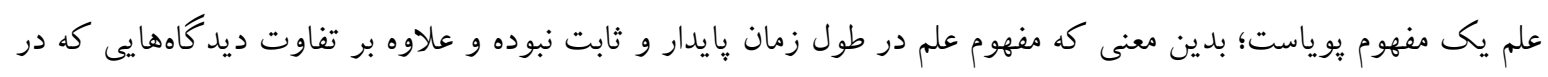

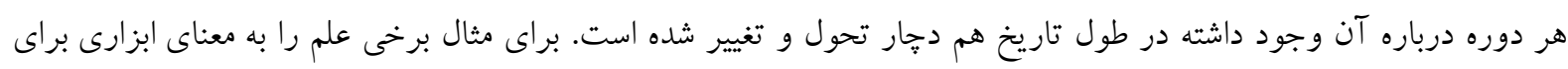

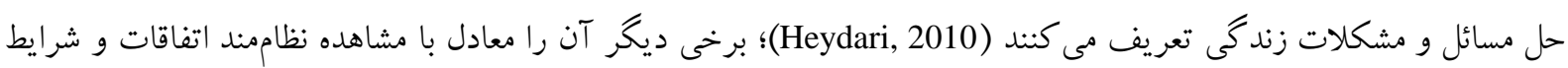

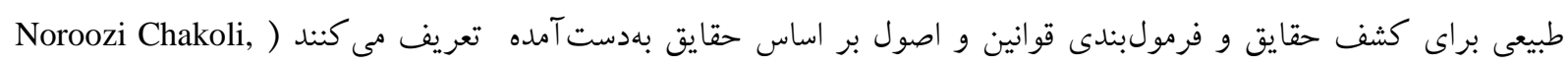

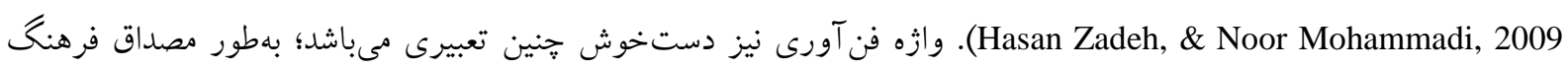

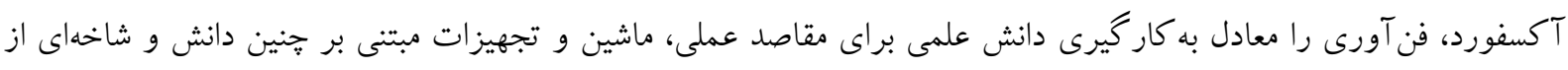

1 David Jablonsky

2 Michael Pillsbury

3 Niall Ferguson

4 Samson Esudu

5 Power in the Global Information Age: from Realism to Globalization 
دانش كه با علوم كاربردى سرو كار دارد تعريف مى كند (Oxford University, 1997). برخى ديخر فن آورى را به معناى يك

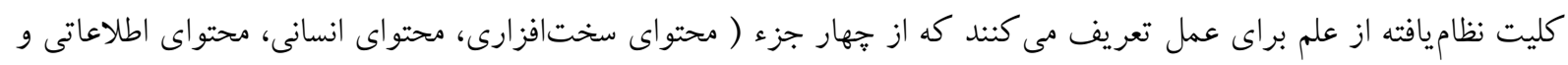

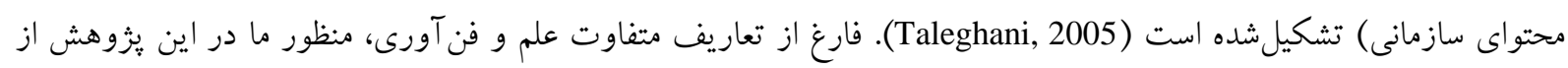

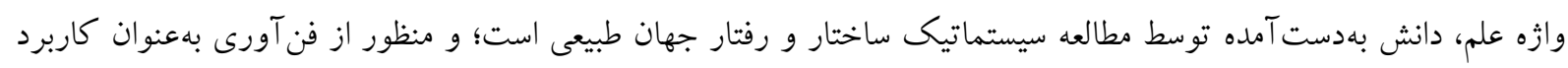

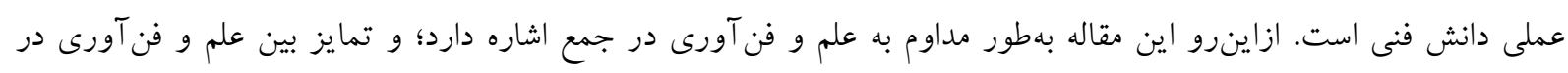
اصل معتبر باقى مانده است.

\section{يافتهاى يزوهش}

بخش اول؛ يافته هاى تحليلى

\section{نقش مؤلفه علم و فن آورى در ايجاد و تقويت قدرت نظامى}

همانند قدرت ملى، در توليد و تقويت بعد نظامى قدرت، عوامل انسانى، سياسى، اقتصادى، جغرافيايى، علمى و ... نقش آفرين

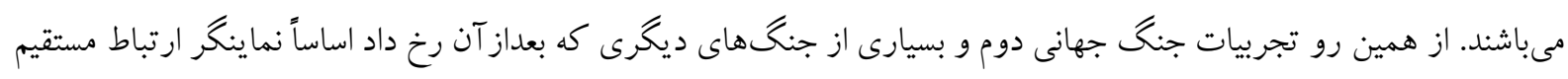

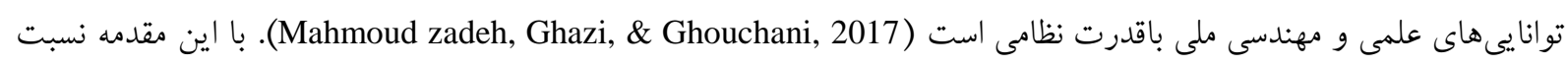

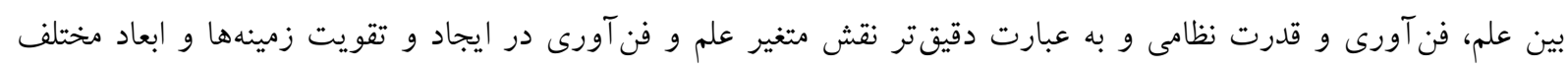

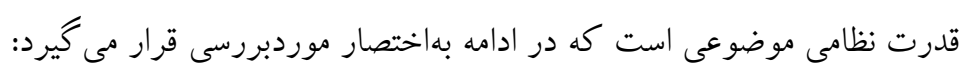

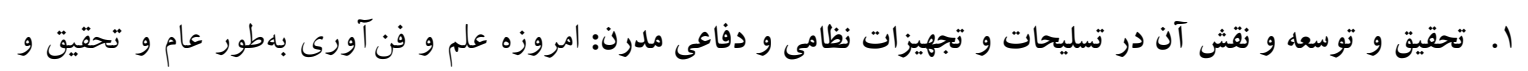

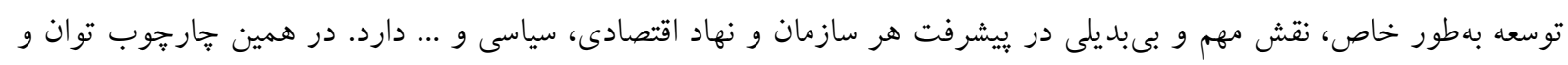

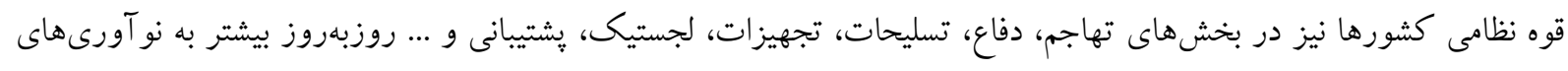

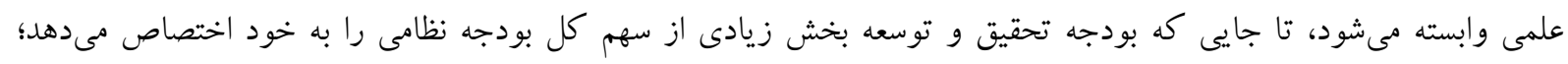

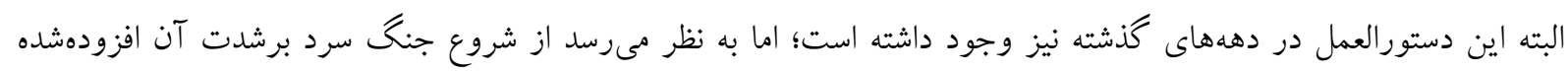

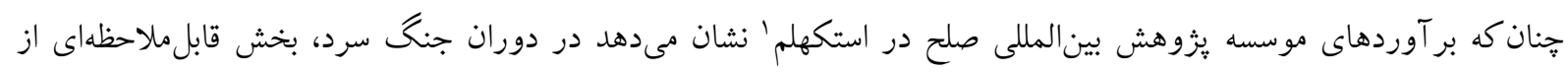

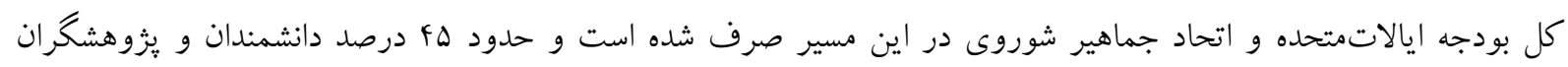

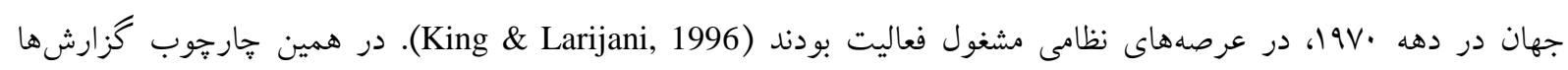

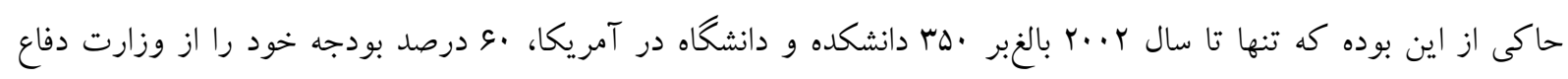
تأمين مى كردند (Modares, Khalili, \& Ata Negad, 2017)

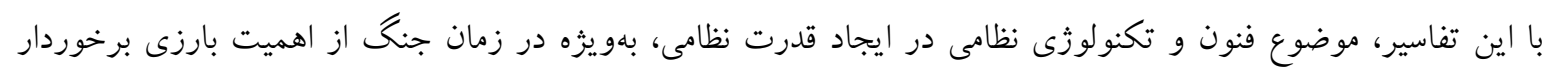

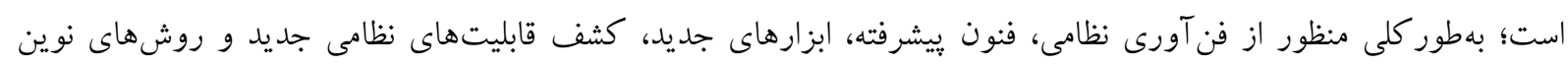

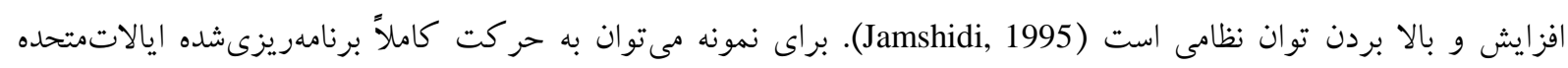

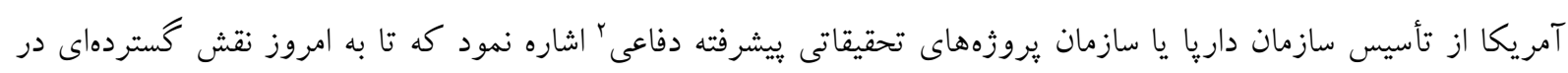
تعامل عميق بين رهبرى نظامى آمريكا و رهبرى فن آورى آن داشته است (National Research Council, 2009). 


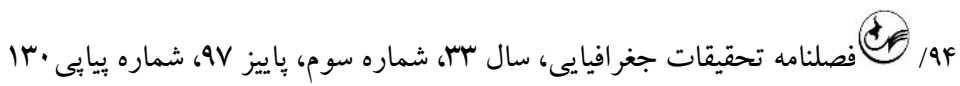
r. ت. توليد تسليحات بيشرفته و استراتزيك: كسب دانش از طريق يزوهش و آموزش و استفاده از آن، بهويزه دانشهاى

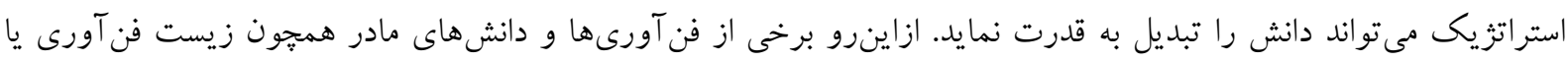

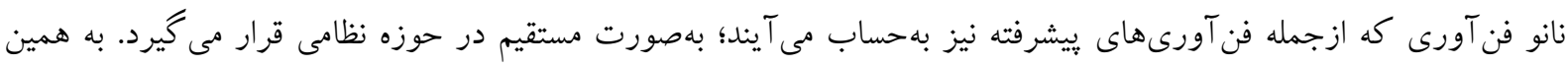

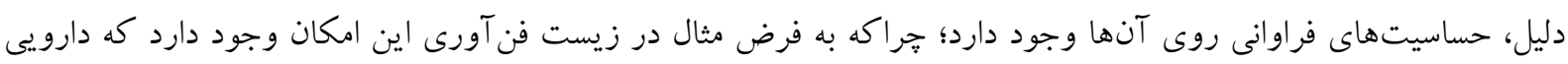

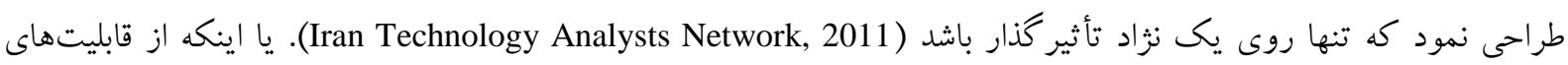

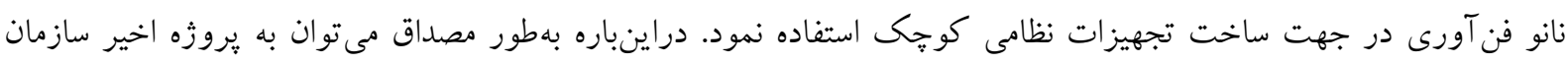

داريا، در جهت استفاده از حشرات براى استفاده جاسوسى اشاره كرد (The guardian News Website, 2006).

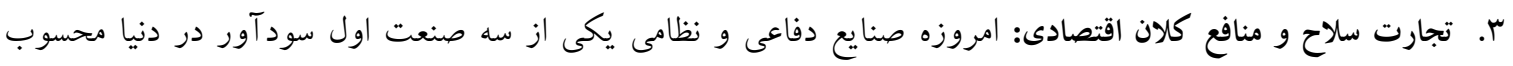

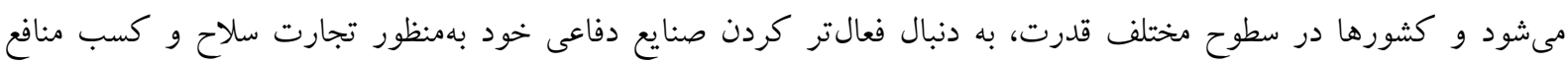

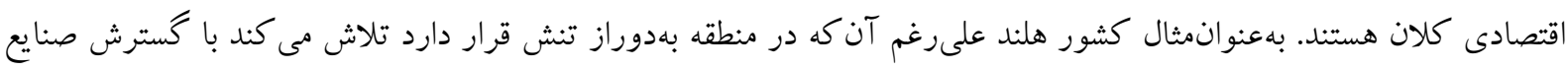

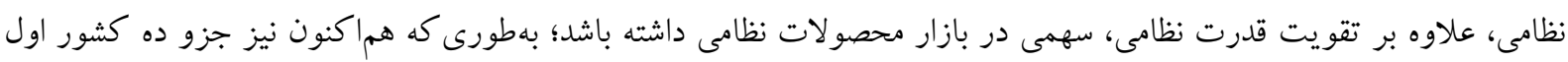
صادر كننده تسليحات نظامى محسوب مىشود (Stockholm International Peace Research Institute, 2018). اما نكته

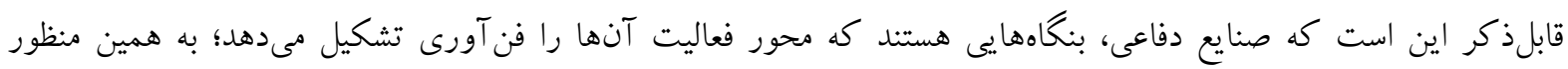

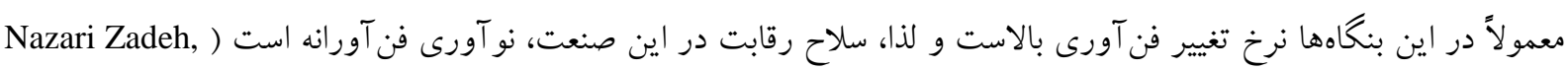
Mehdi Nejad Nouri, \& Hejazi, 2014

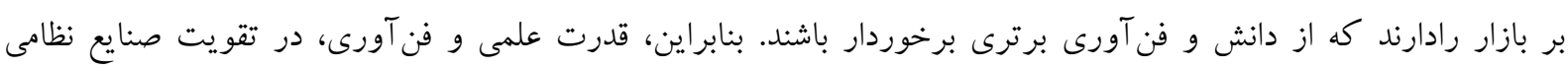

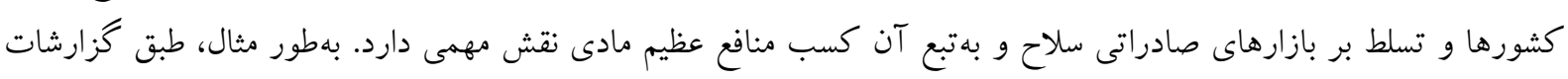

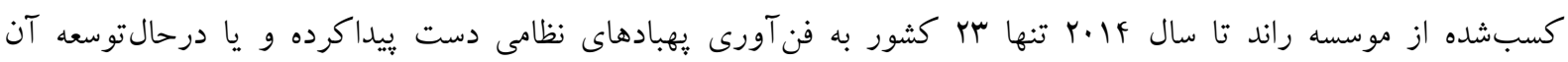

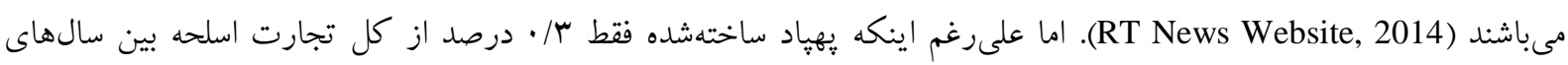

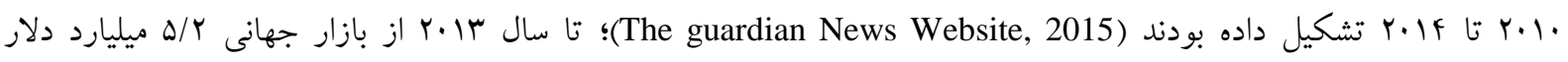

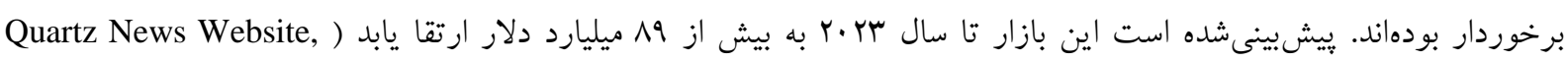

f. قدرت علمى و ايجاد توان بازدارندگى نظامى: تأثير ديخر علم و فن آورى در حوزه نظامى از طريق بازدارندگى

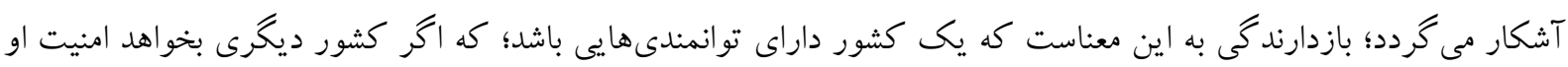

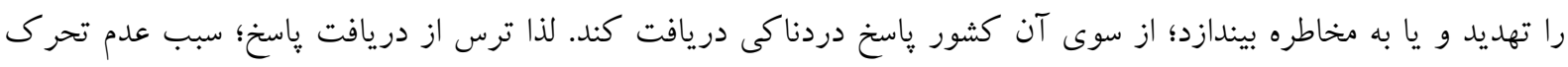

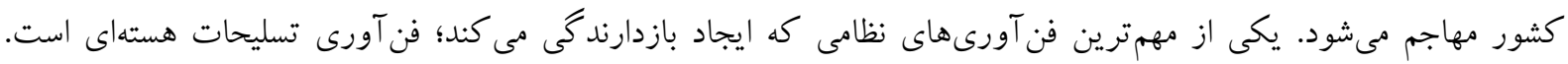

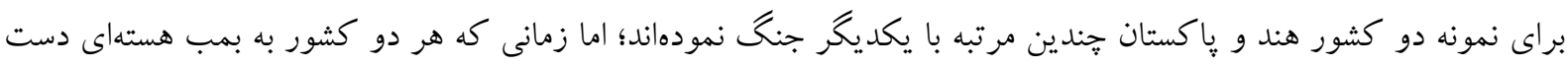
ييدا كردند؛ هيج نزاع جدى ميان دو كشور صورت نكخرفته است (Iran Technology Analysts Network, 2011).

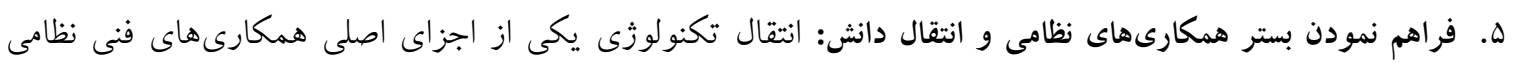

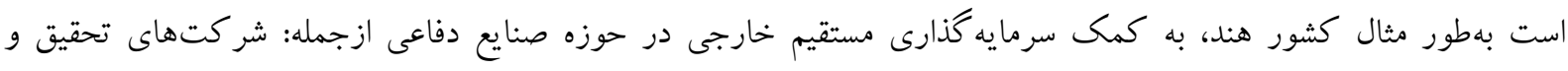
توسعه، سرمايه كذارى مشترك و شر كتهاى توليد محصولات دفاعى زمينه اين نوع همكارى را براى خود فر هراهم ساخته است.

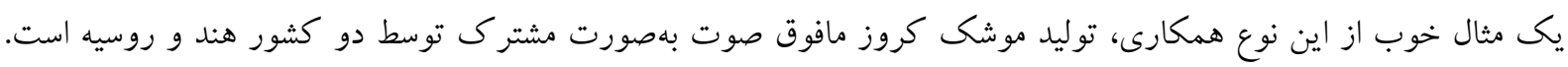

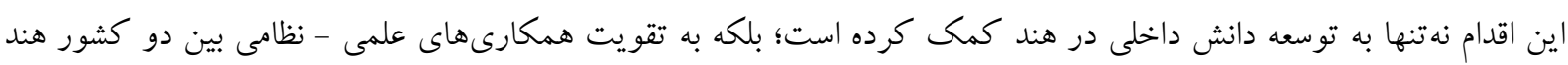


و روسيه نيز منجر شده است (Mallik, 2016). از طرف ديخر، اين نوع تعاملات منحصر و محدود بر همكارى بين سطوح

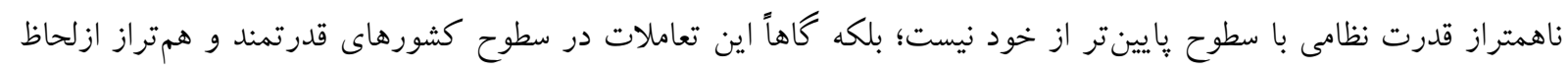

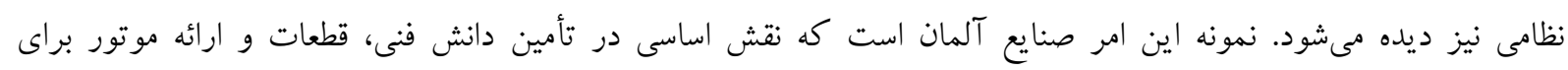

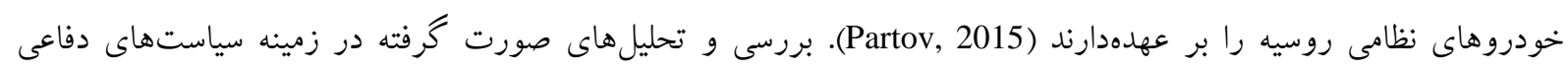

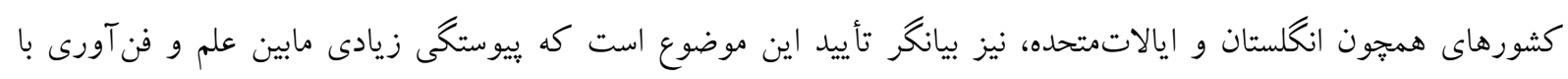

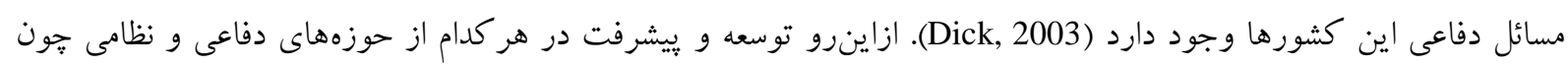

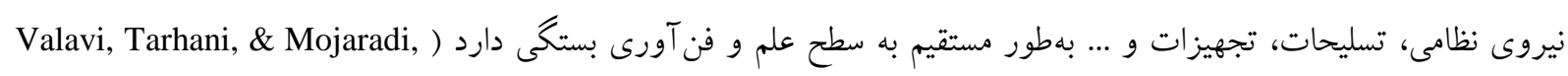

2011

\section{نقش مؤلفه علم و فن آورى در ايجاد و تقويت قدرت اقتصادى}

ثزوهشهاى صورت گرفتهشده در نيمه دوم قرن بيستم نشان داد؛ علم بهمنزله نيرويى مستقل و خودگردان در اقتصاد و

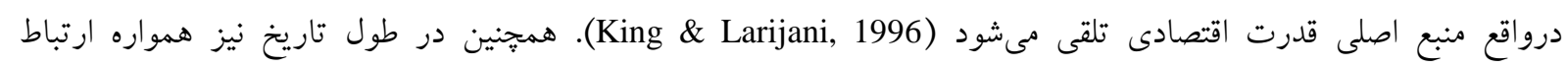

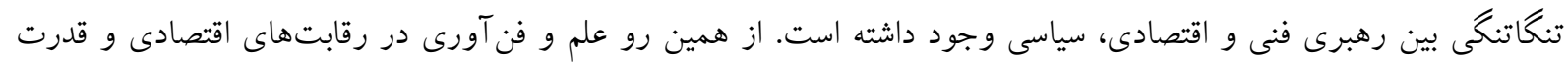

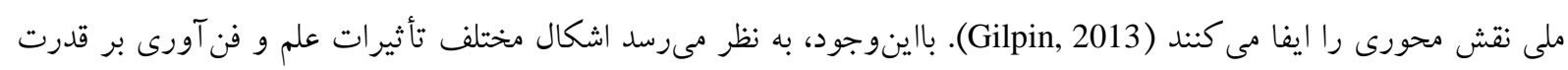
اقتصادى مى تواند بهصورت زير باشد:

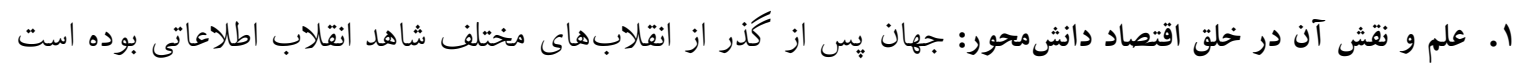

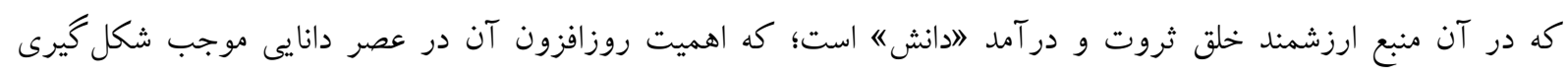

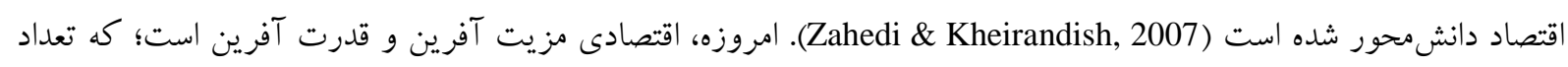

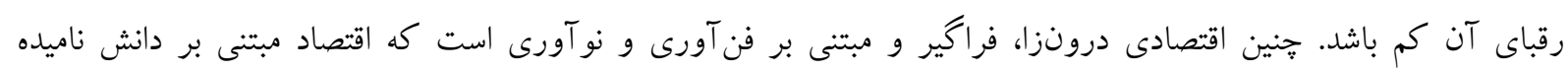
مىشود (Faraji Rad \& Abdi, 2015). ازنظر سازمان همكارى اقتصادى و توسعه، اقتصاد دانش محور، اقتصادى است كه فئ مستقيماً

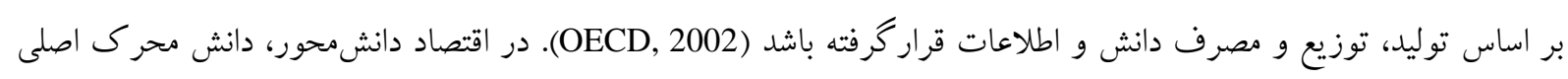

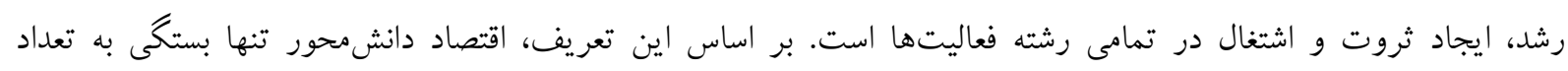

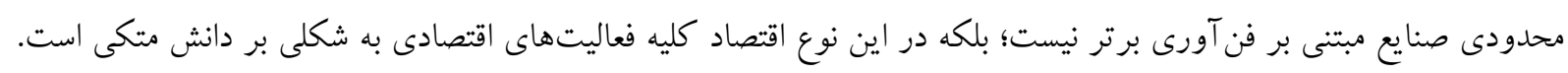

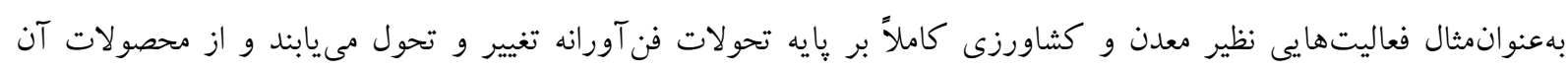

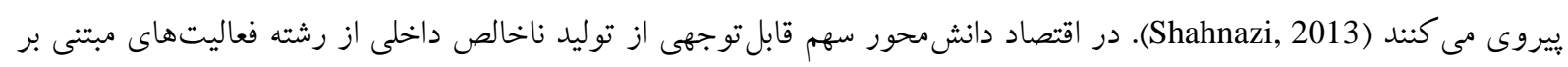

دانش و دانش بر مانند صنايع با فن آورى برتر و متوسط و خدمات مالى و تجارى دانشمحور كسب مى شود (Oت (OECD, 1996).

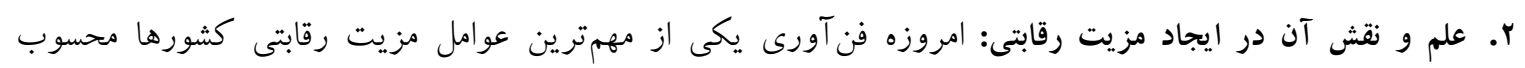

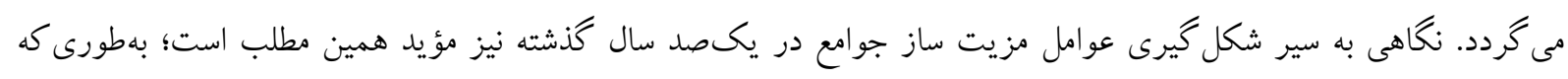

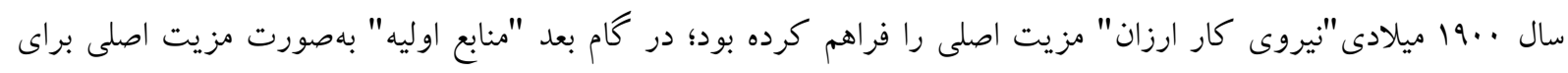

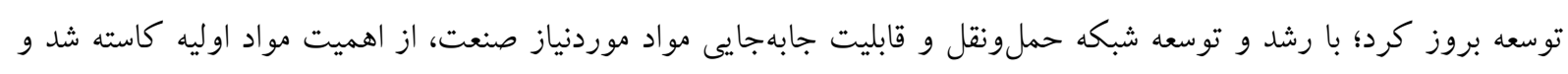

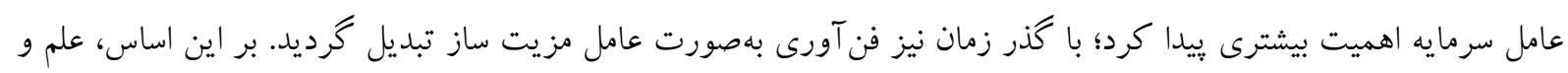

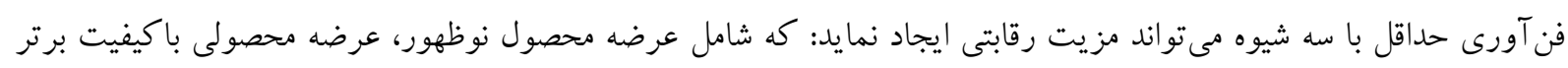
و عرضه محصول ارزانتر مى باشد (Mirzaei \& Abdi, 2003). 


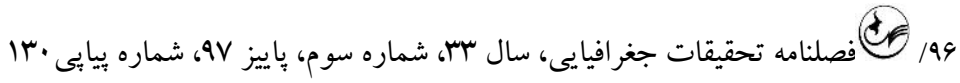
r. علم، اقتصاد دانشبنيان و رشد اقتصادى: اقتصاد مبتنى بر علم و فن آورى، اقتصادى نو آورانه، رقابت پيذير و مبتنى بر

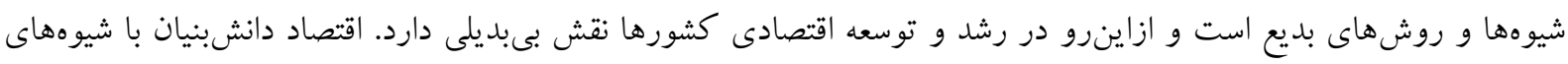

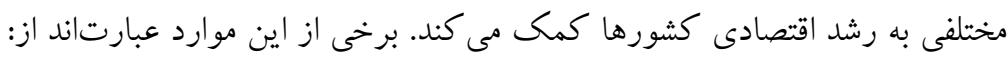

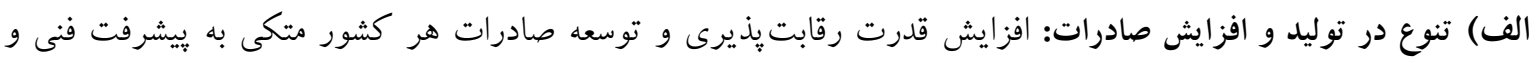

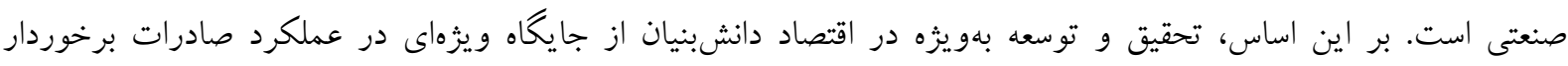

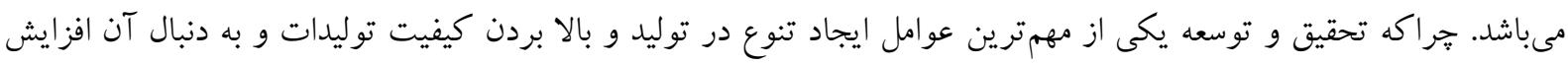

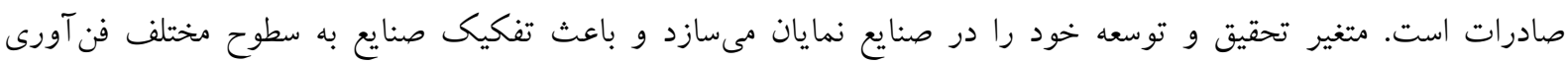

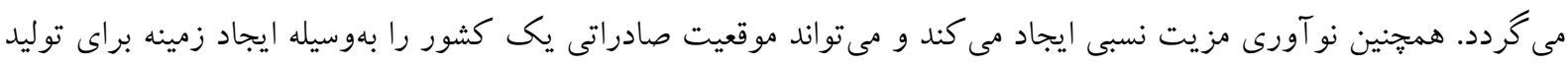

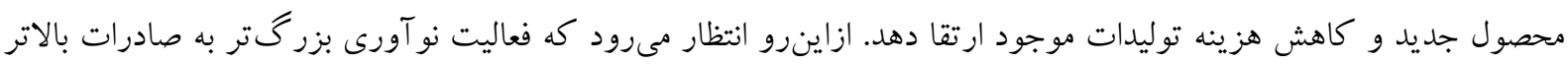

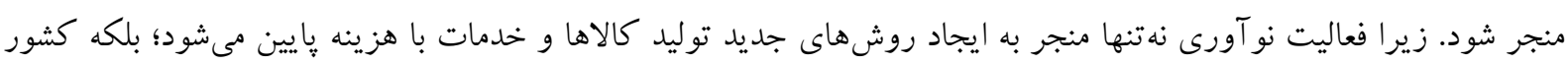

را در موقعيت رقابتى بهتر نسبت به رقباى تجارى آن قرار مىدهد (Deh Moobed, Mehregan, \& Dehghan Poor, 2011)

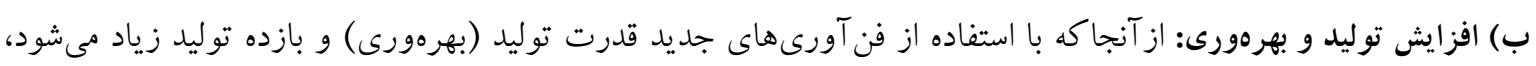

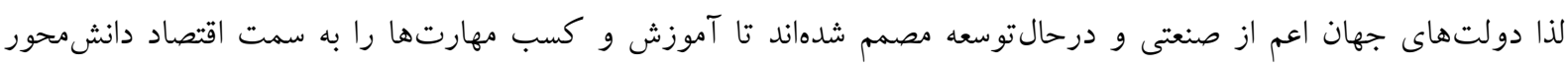

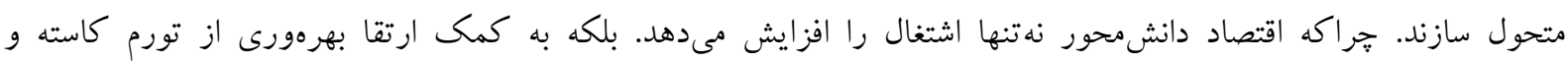
در آمدها را افزايش مىدهد (Sadeghi \& Azarbayejani, 2006).

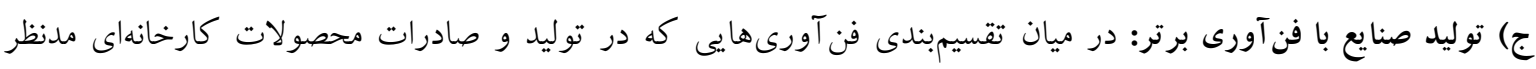

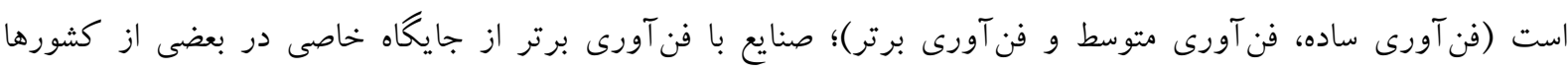

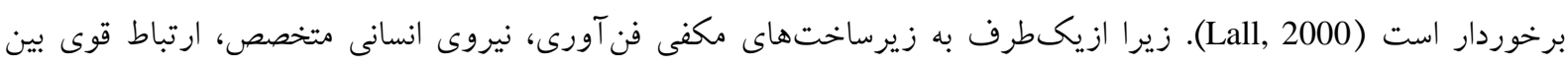

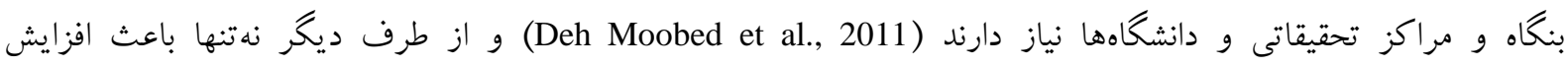

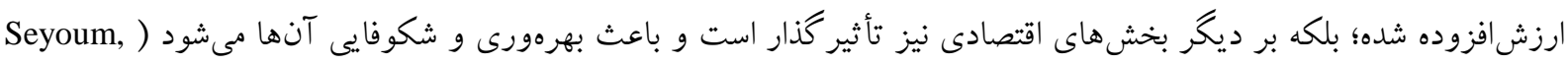

د) افزايش توليد ناخالص داخلى: اقتصاد دانشمحور از طريق يزوهشهاى جديد فن آورى در بخشهاى مختلف اقتصادى و

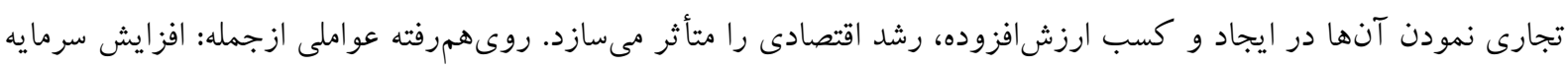

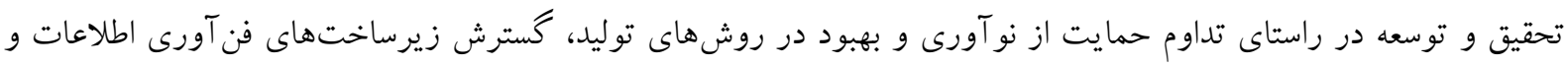

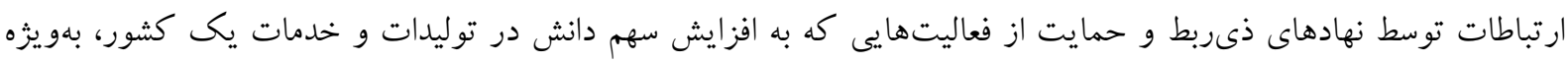

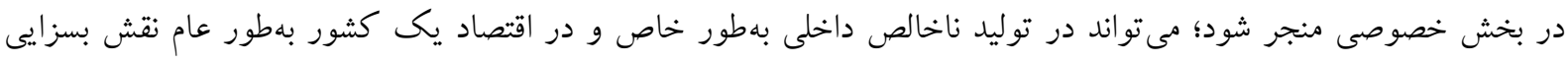

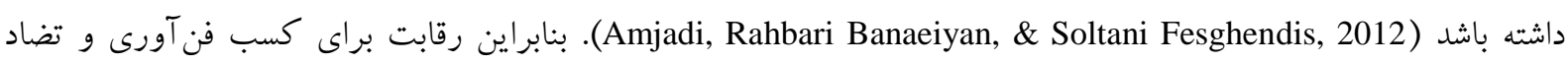

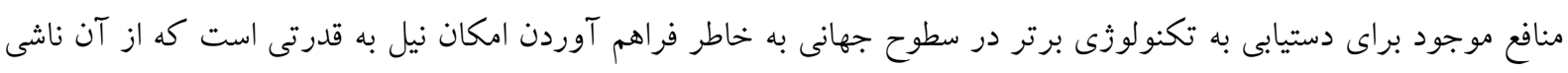
مىشود (Haj Fathaliha, 1993).

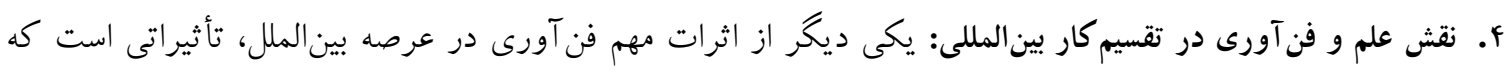

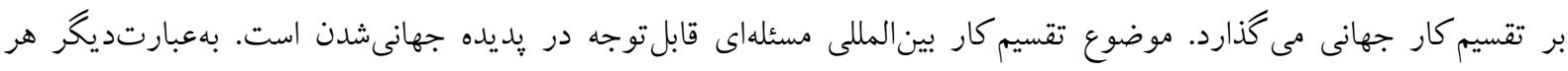

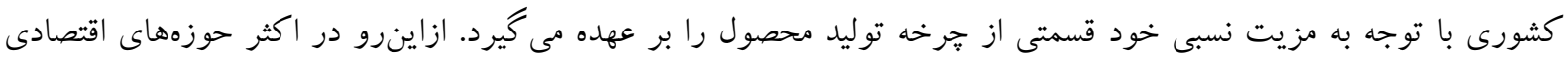

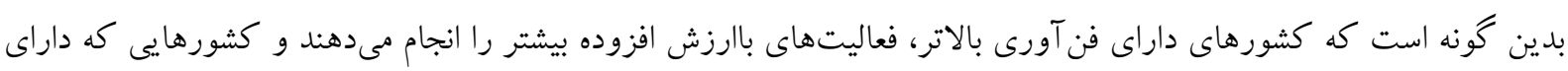


فن آورىهاى متوسط و پايينترند، فعاليتهايى بارزش افزوده كمتر و بهاصطلاح كاربر را انجام مىدهند. براى نمونه در خرخه

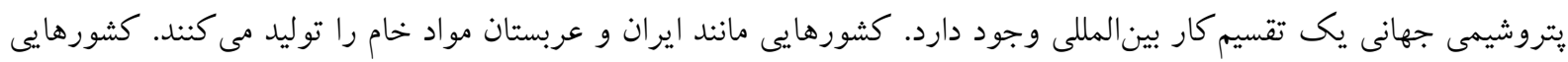

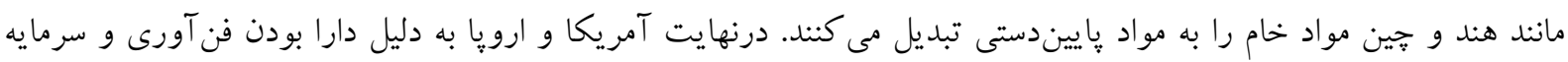

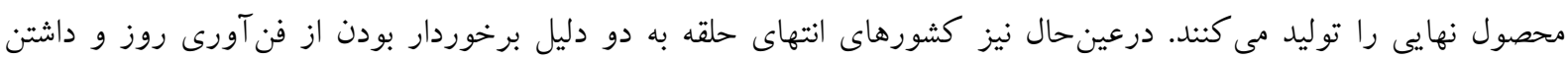

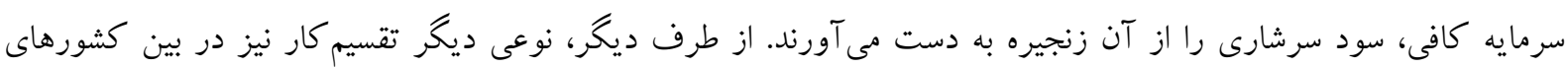

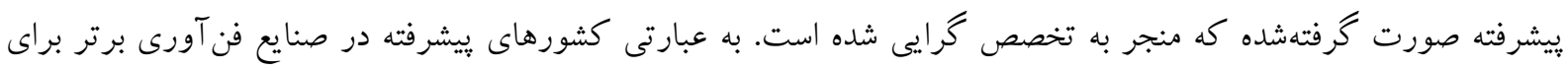

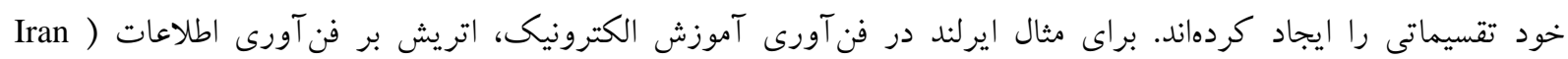

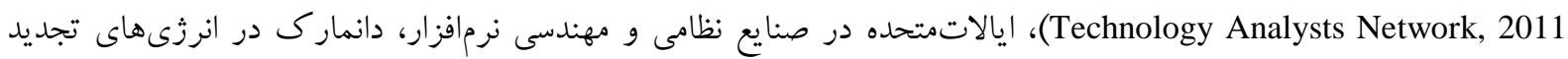

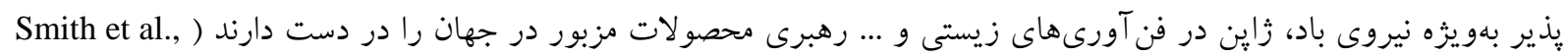

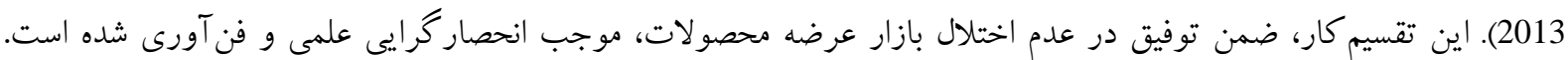

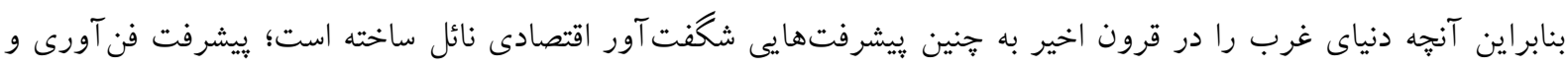

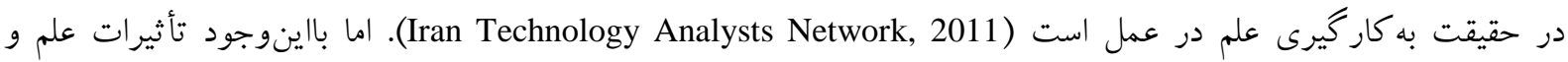
فن آورى بر قدرت اقتصادى بهصورت متقابل است و بهصورت يكسويه و تنها منحصر از سوى علم و فن آورى نيست؛

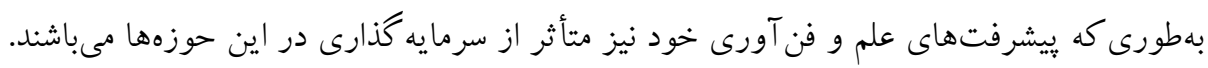

\section{نقش مؤلفه علم و فن آورى در ايجاد و تقويت قدرت فرهنگى}

اگر فرهنگ را در قالب مجموعه دانشها، اعتقادات، هنرها، اخلاقيات، قوانين، رسوم و هر گونه توانايى و عادت ديخرى كه

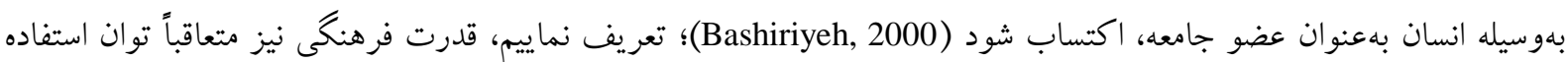
از اين امكانات و خصيصههاى ساختارى و ذهنى در جهت دستيابى به اهداف از ييش طراحىشده تعريف مىشود. از اين حيث،

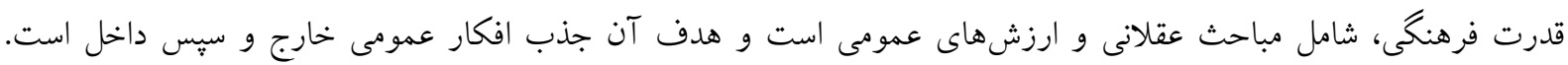

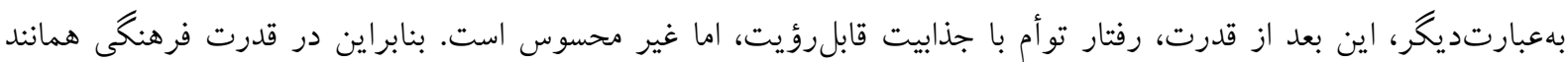

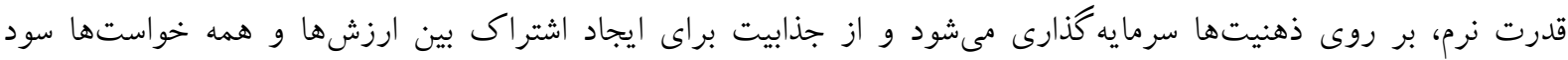

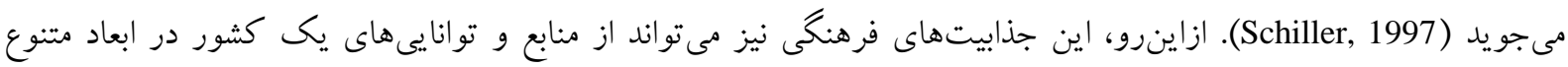

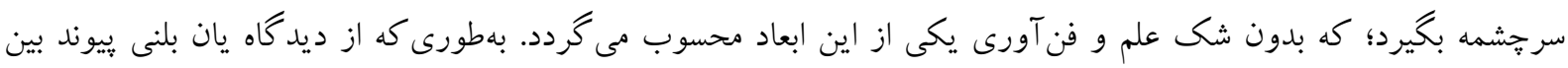

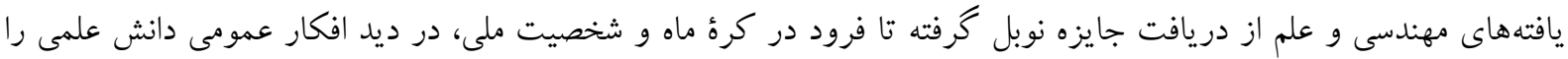

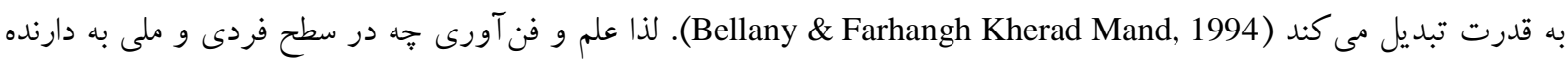

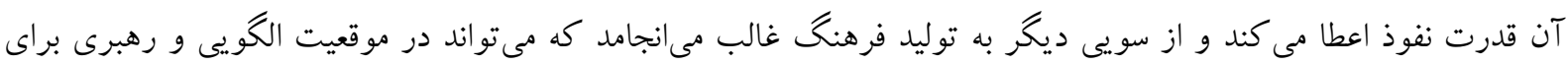

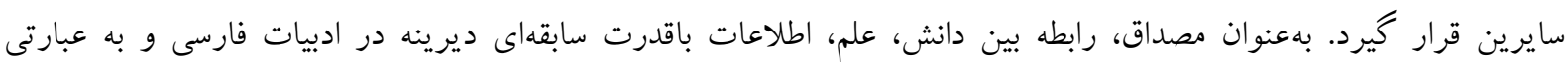

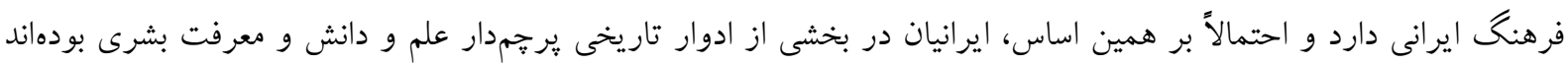

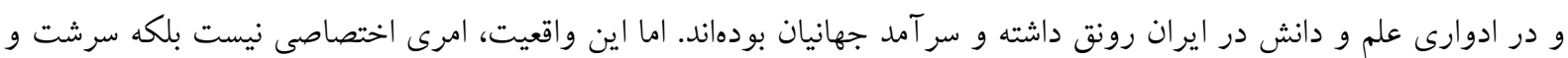

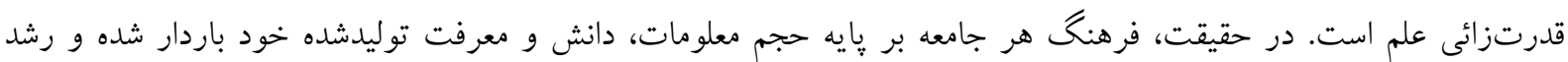

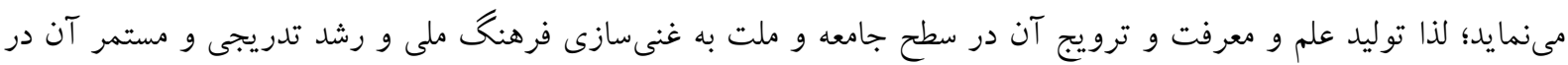

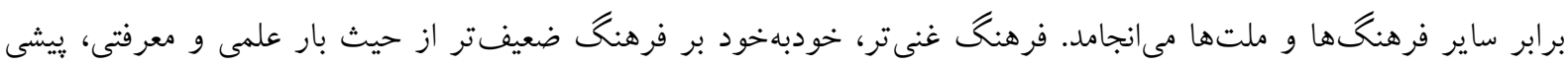

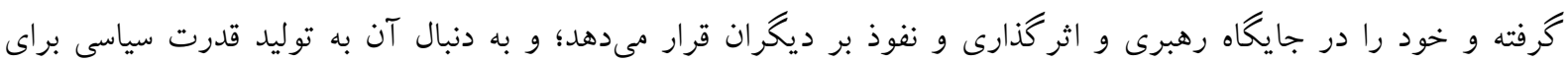




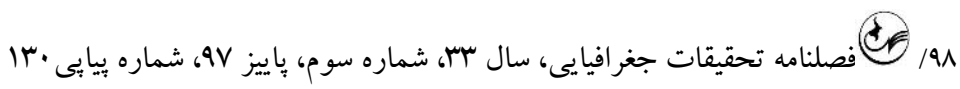
جامعه و ملت يِش روى خود مى يردازد (Hafez Nia, 2011). از طرف ديخر قدرت فرهنكى شامل دو بعد ارزشى و علمى است؛

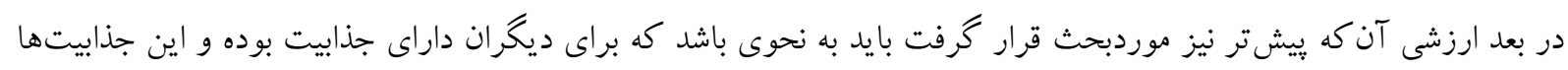

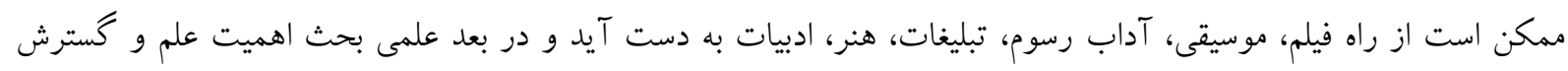

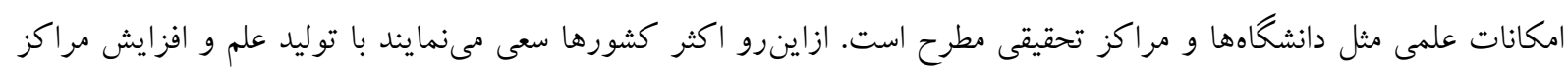

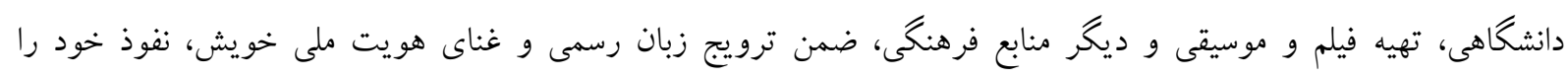

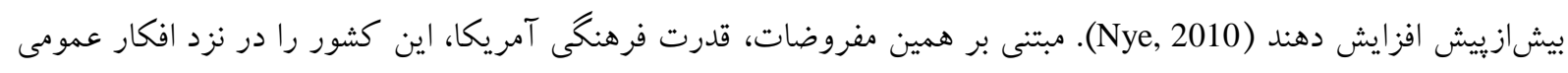

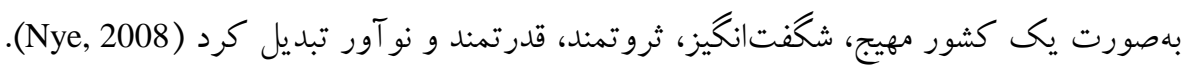
نقش مؤلفه علم و فن آورى در ايجاد و تقويت قدرت سياسى بهطور كلى بيامدهاى علم و فن آورى بر فاكتور سياسى قدرت ملى در دو سطح خرد و كلان قابلتحليل مىباشد؛ از نخاه

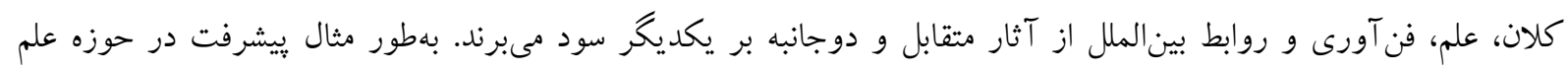

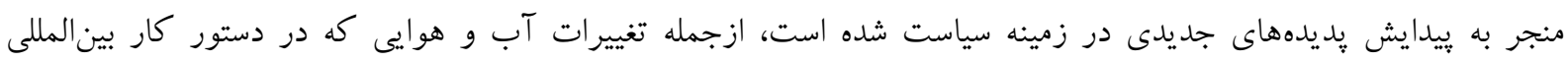

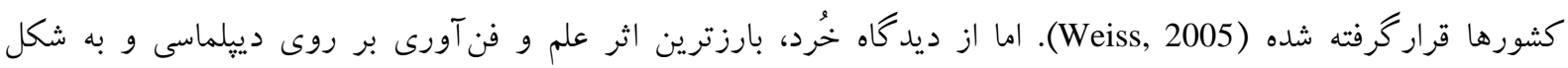

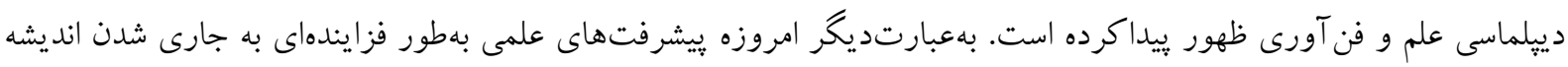

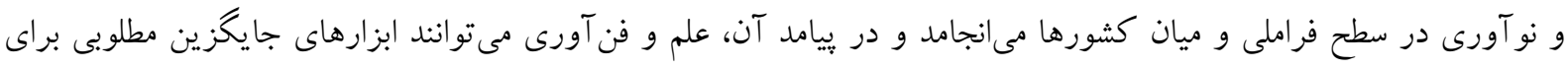

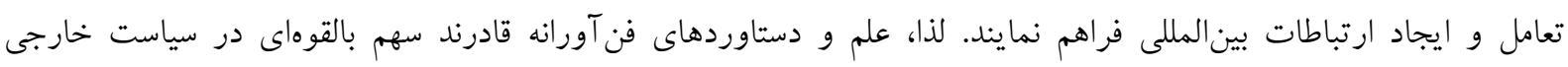

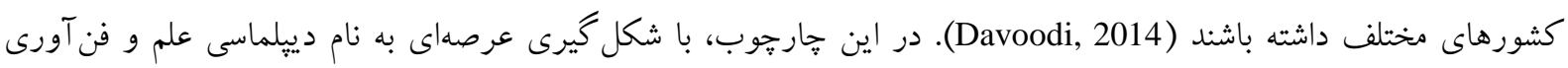

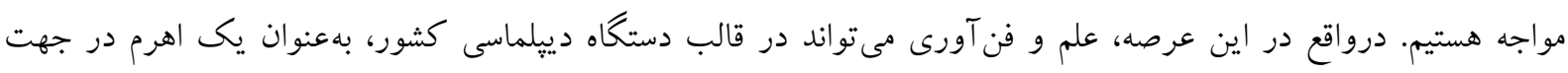
اثر كذارى بر قدرت سياسى و سياست خارجى يك كشور به كار كرفته شود (Iran Technology Analysts Network, 2011).

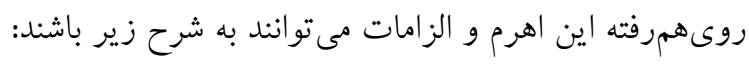

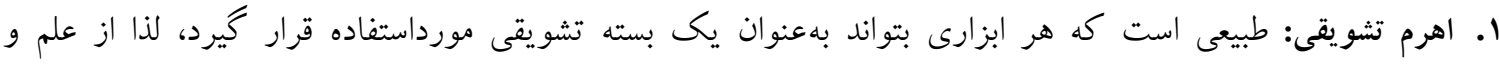

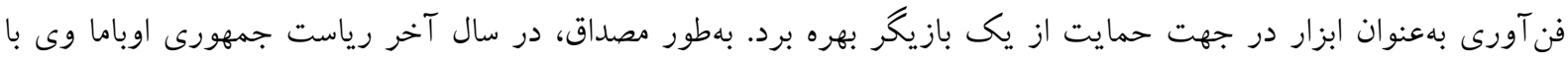

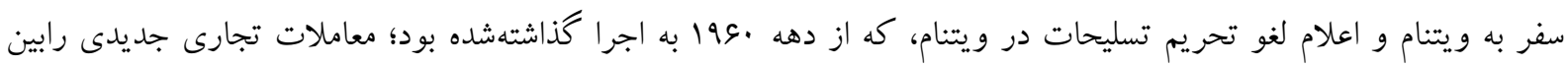

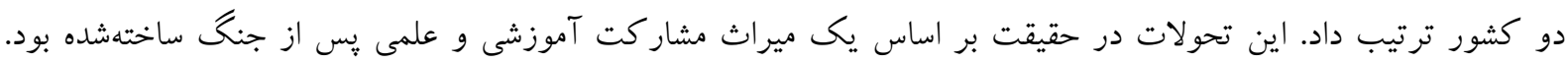

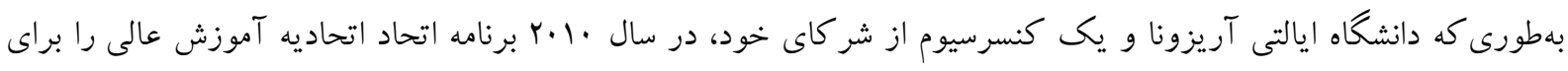
مدرنسازى و تقويت دانشكاههاى فنى ويتنام تأسيس كرد (Turekian, 2016).

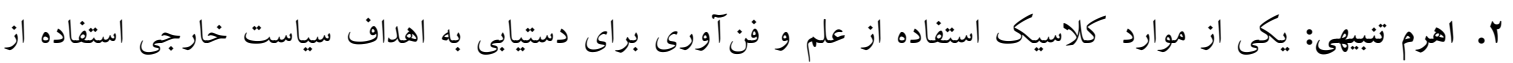

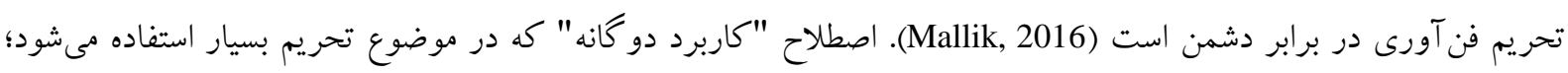

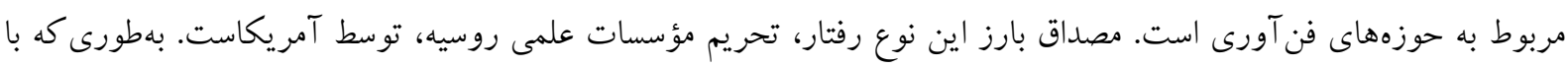

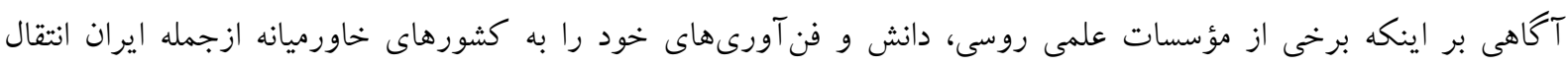

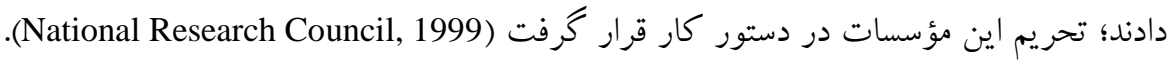

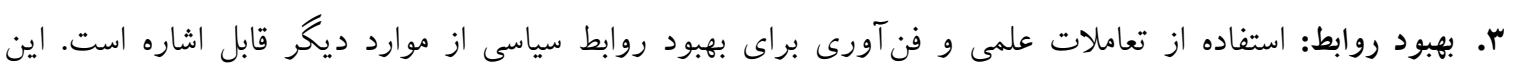

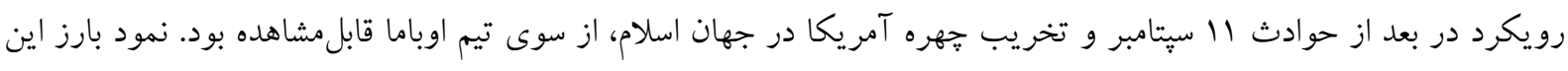

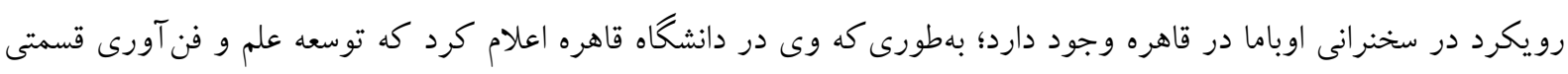


از رويكرد او در تقويت روابط صلح آميز است (SciDev News Website, 2009). بر اساس همين رويكرد جوامع تحقيقاتى در

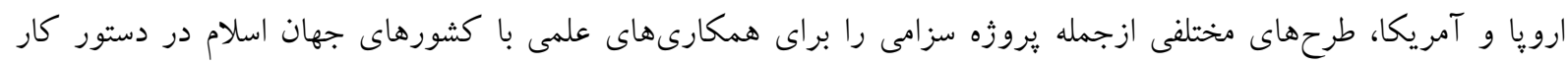
قراردادند تا بتو انند روابط شكننده را بازسازى كنيند.

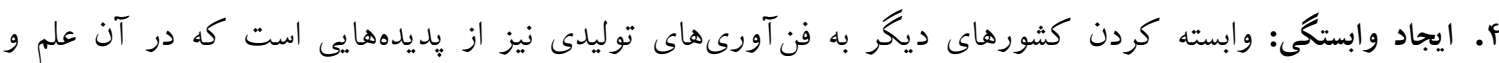

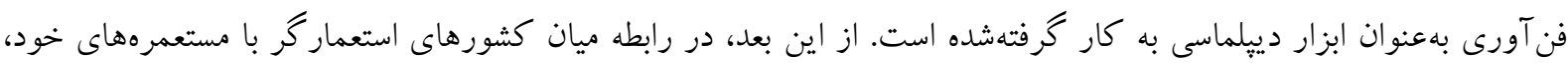

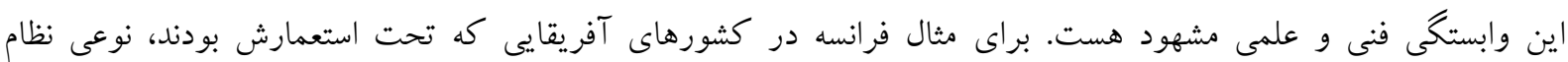

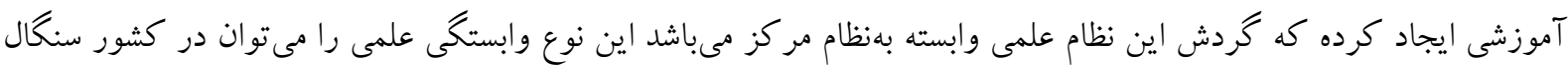
مشاهده نمود (Iran Technology Analysts Network, 2011). ه. اهرم نفوذ در عرصه معاهدات بينالمللى و حقوق بينالملل: بررسى روند فعاليتهاى كشورهاى بيشرفته نشان مىدهد كه

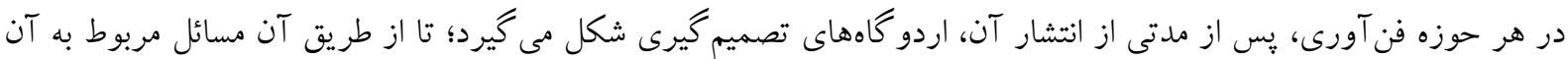

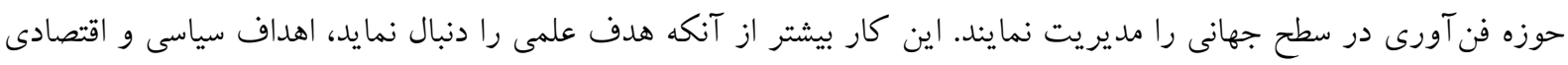

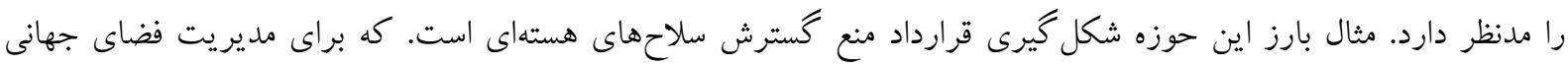

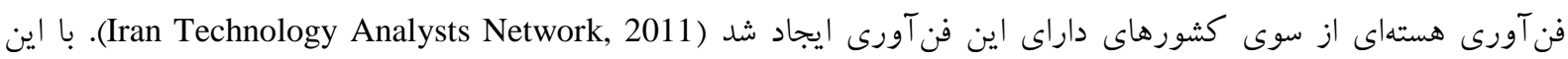

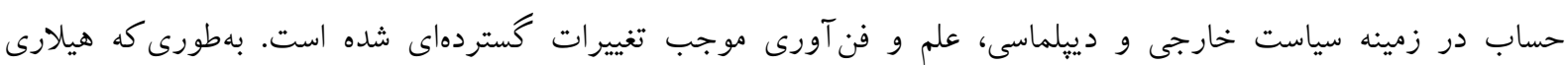

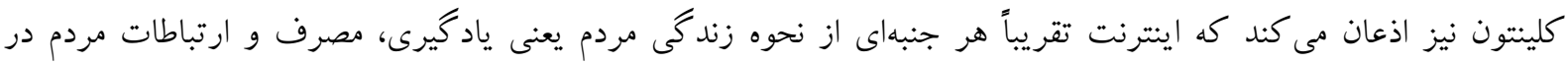

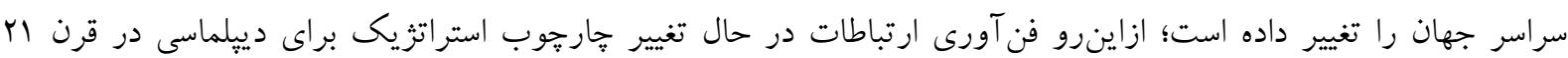

است (Kluz \& Firlej, 2015).

\section{نقش مؤلفه علم و فن آورى در ايجاد و تقويت قدرت زئو يليتيكى}

بخشى از عوامل و سرحشمههاى قدرت ملى يك كشور در جغرافياى آن قرار دارند؛ كه در يك نماى كلى شامل موقعيت

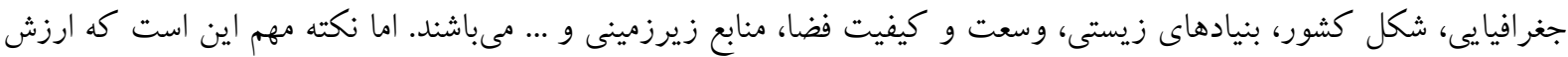

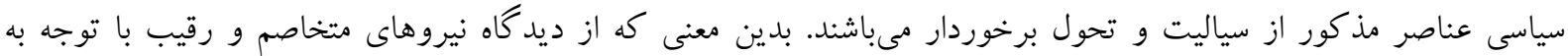

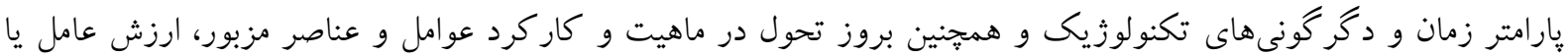

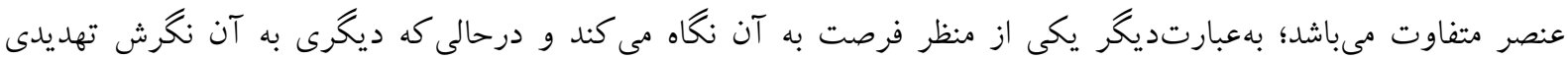

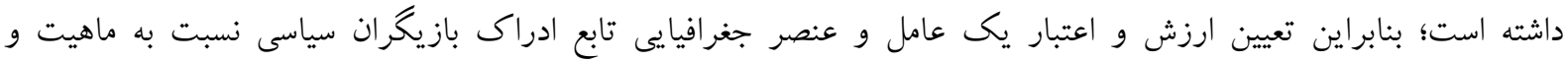

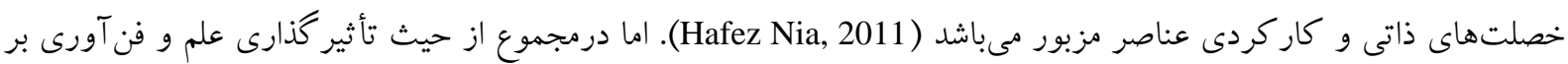

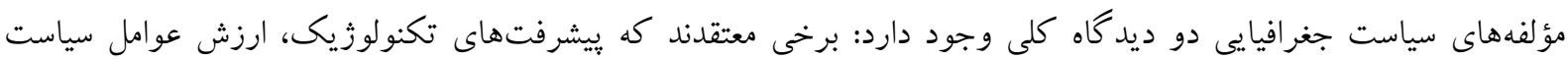

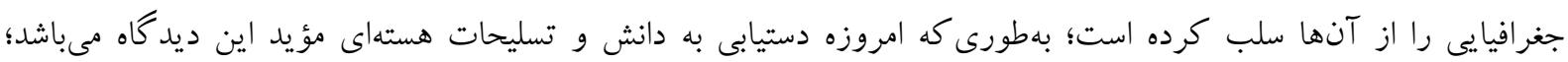

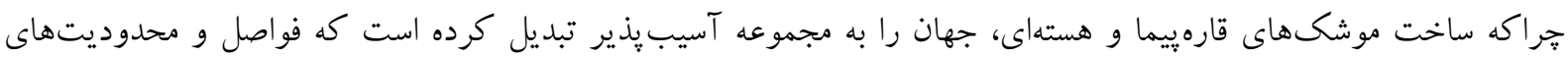

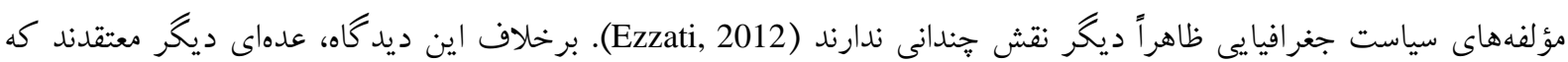

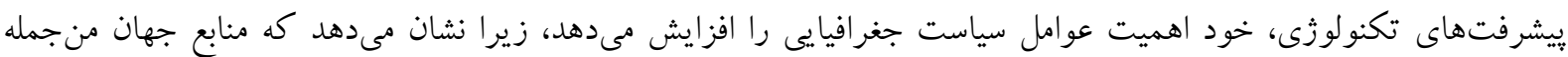

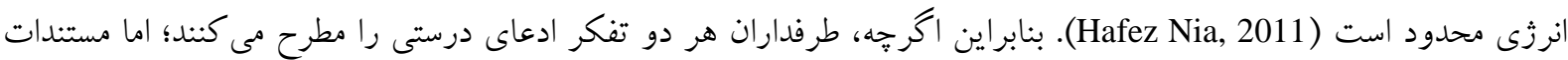

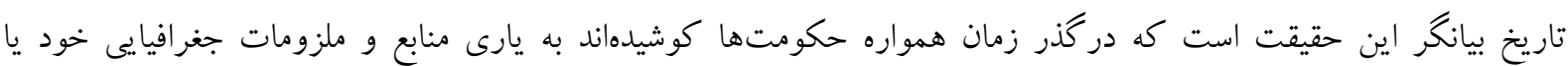

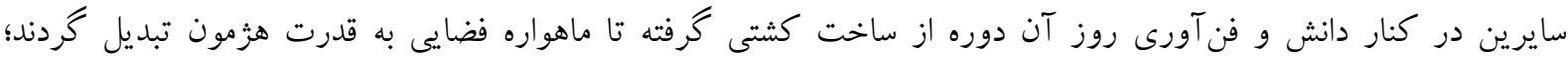


II....

بنابراين اگرجه بدون منابع و بنيادهاى زيستى هيج گونه هواييما، اتومبيل، موتور جت، سفينه، اسلحه يِيشرفته و حتى وسيله

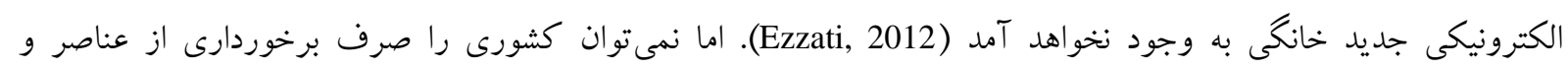

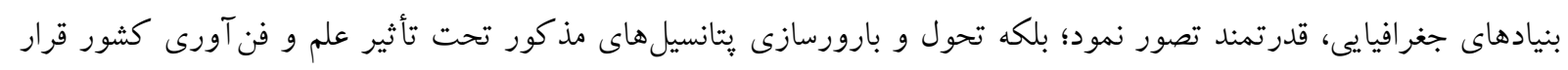

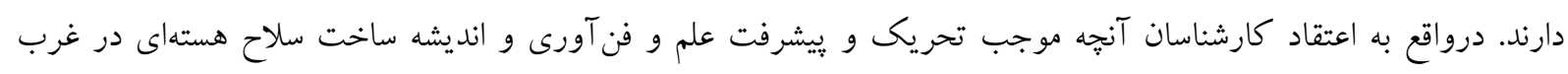

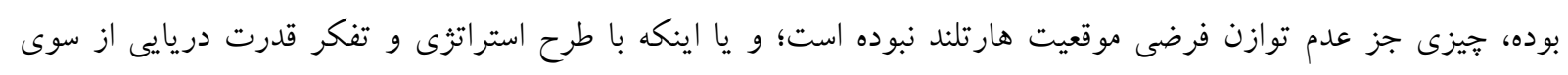

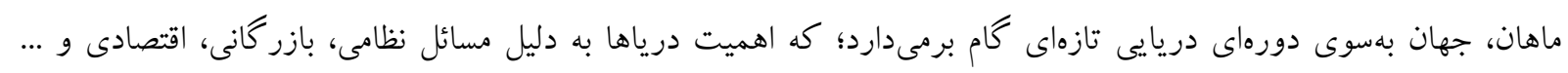

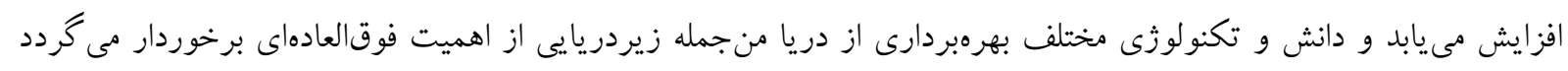

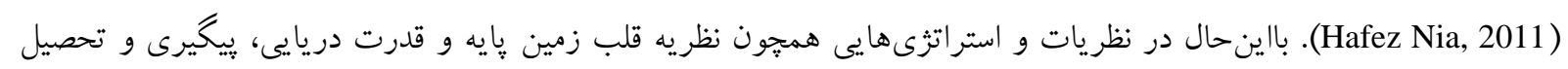

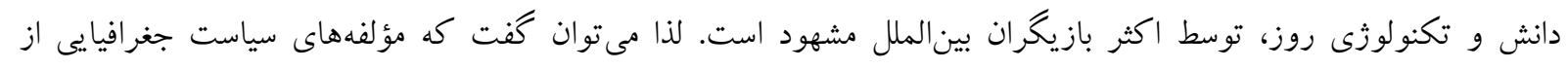

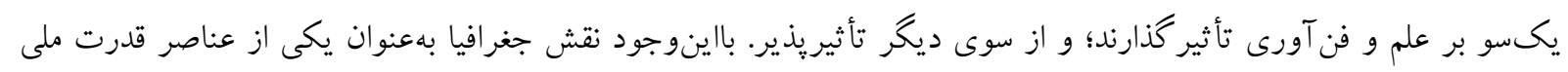
وابسته به عناصر ديخر، مانند جمعيت، سطح توسعه علمى و صنعتى وسايل حملونقل و و ارتباطات و مانند آن مى دياشد.

نقش مؤلفه علم و فن آورى در ايجاد و تقويت قدرت اجتماعى به اذعان برخى از نظريه يردازان جغرافياى سياسى و روابط بينالملل بخشى از قدرت ملى يكى كشور در ويثگى و شرايط

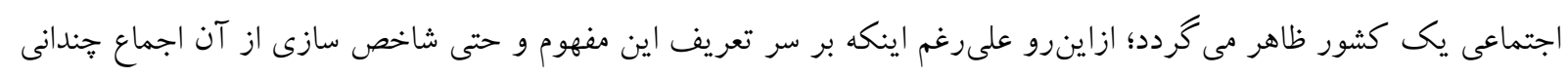

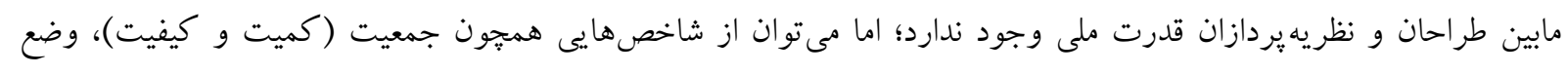

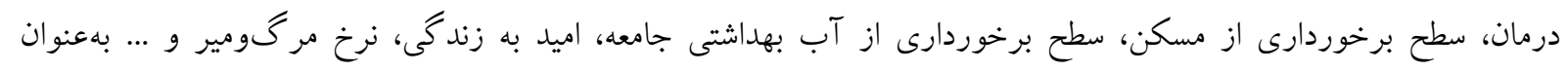

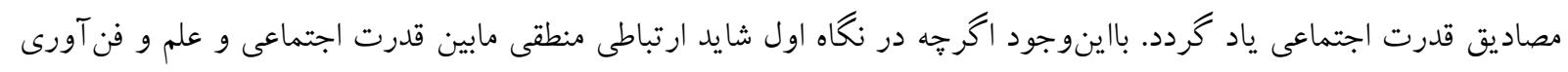

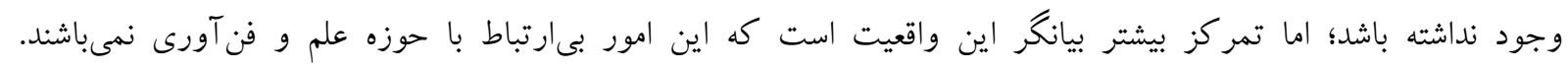

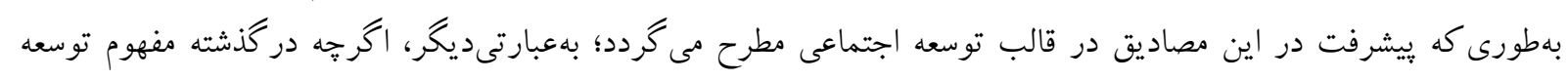

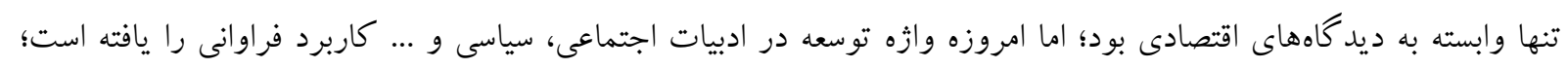

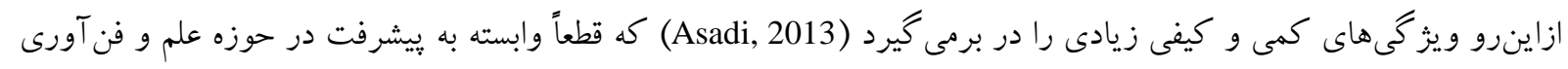

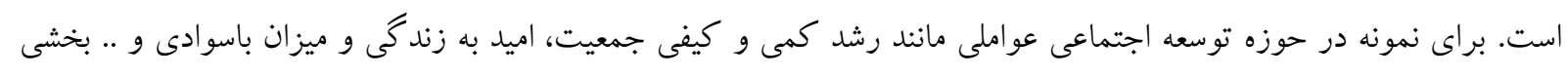

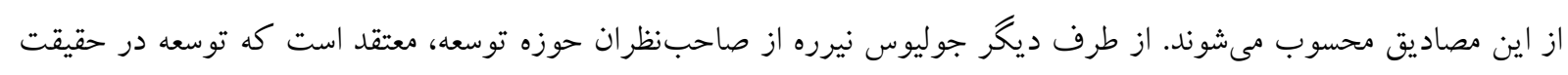

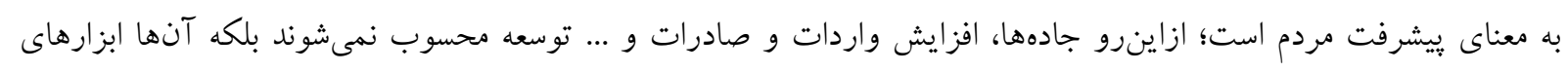

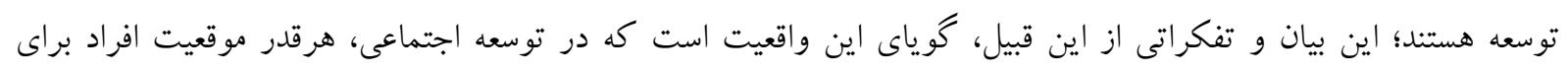

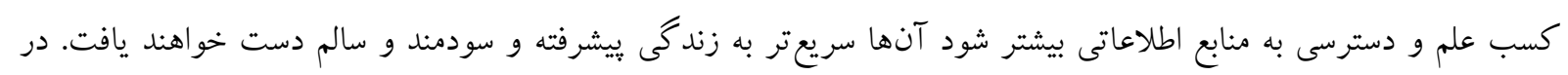

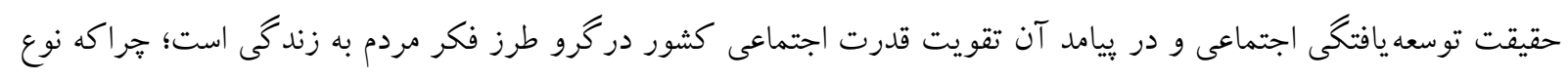

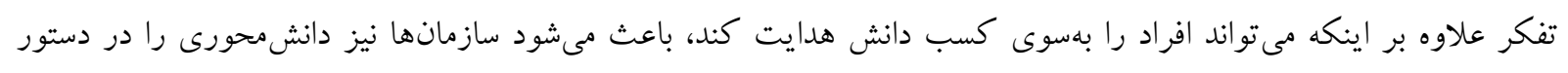

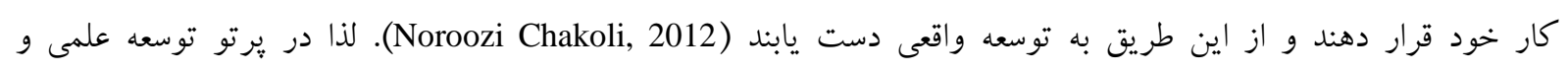

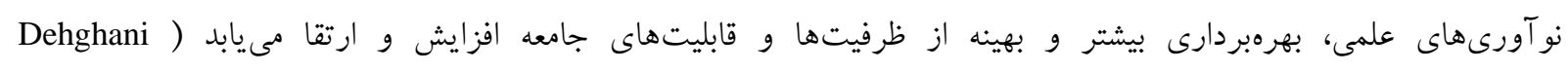

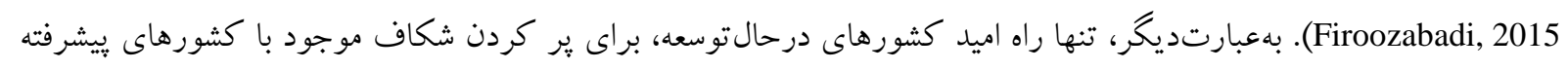

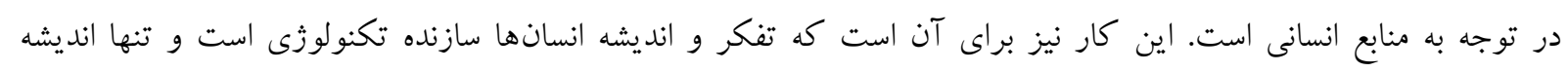

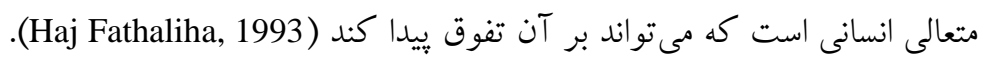




\section{بخش دوم؛ يافتهاى ميدانى يزوهش}

مطابق با جشمانداز يزوهش، يرسشنامهاى در قالب ع سؤال بهصورت طيف ليكرت و به دو زبان فارسى و انكليسى در

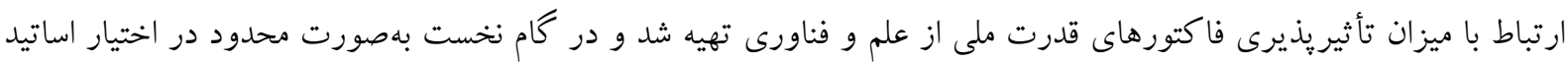

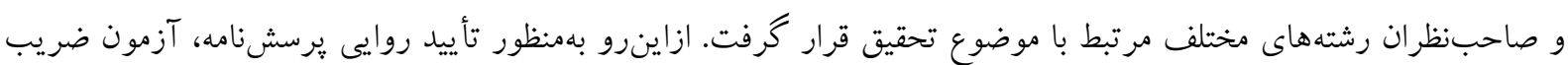

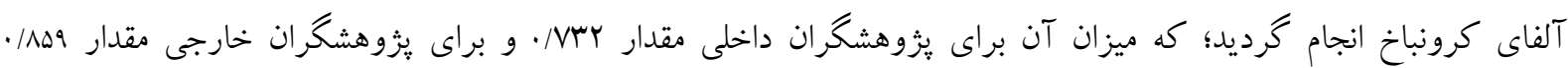

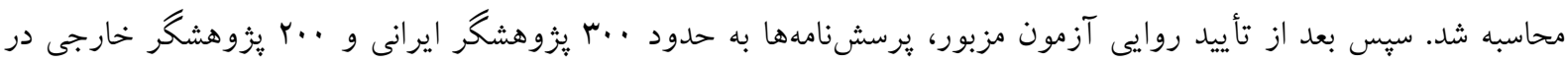

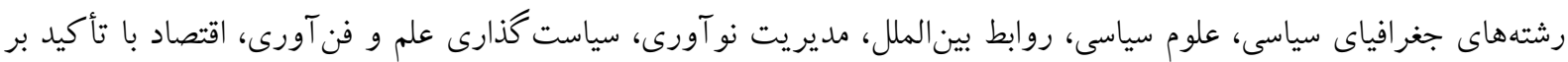

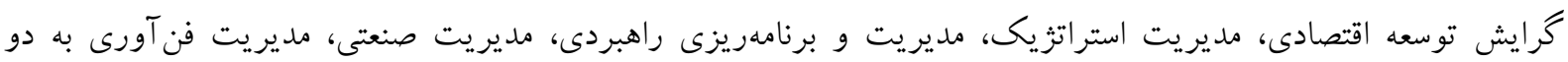

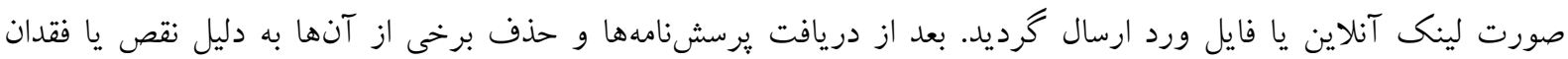

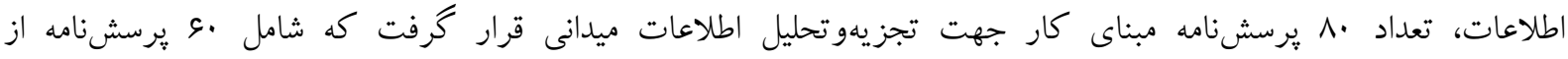

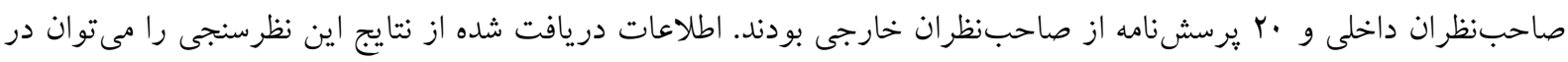
قالب جدول ا خلاصه نمود.

جدول ا-نتايج تحليل اطلاعات توصيفى از يرسشنامههاى دريافتى

\begin{tabular}{|c|c|c|c|c|c|c|}
\hline \multirow{2}{*}{ ميانكين نمره } & \multicolumn{5}{|c|}{ درصد فراوانى نسبى كزينهها } & \multirow{2}{*}{ 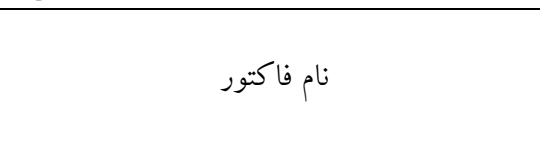 } \\
\hline & خيلى زياد & زياد & 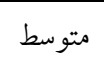 & ك & خيلى كم & \\
\hline$F / G \cdot T V$ & $\%, \& \Delta / \Lambda$ & $\%$ & $\% / 1$ & . & . & ميزان تأثير گذارى فاكتو رهاى علم و فن آورى بر \\
\hline$\Gamma / \Lambda \cdot \Delta \varphi$ & $\% \mu / 9$ & $\% \mu / V$ & $\% \cdot r / \Lambda$ & $\% / r$ & $\% 1 / 4$ & ميزان تأثير كذارى فاكتو رهاى علم و فن آورى بر وامل و فاكتورهاى سياسى قدرت ملى \\
\hline$r / s \wedge F q$ & $\%$ & $\% r \cdot / \Delta$ & $\%$ & $\% / \mathrm{N}$ & . & ميزان تأثير كذارى فاكتو رهاى علم و فن آورى بر و فاكو \\
\hline$r / g r \wedge q$ & $\% \cdot r / s$ & $\%$ & $\% / r / s$ & $\% / r$ & $\% 1 / 4$ & ميزان تأثير كذارى فاكتورهاى علم و فن آورى بر \\
\hline$r / \mu \cdot 1 f$ & $\% \mu / \uparrow$ & $\% 19 / r$ & $\% r F / s$ & $\% 11$ & $\% / 11$ & 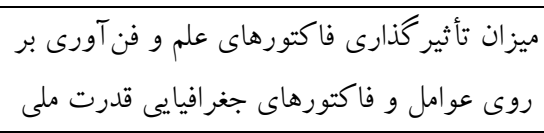 \\
\hline$f / r q V / r$ & $\%$ \% & $\% \cdot r / 1$ & $\% \Delta / \Delta$ & $\% 1 / 4$ & · & 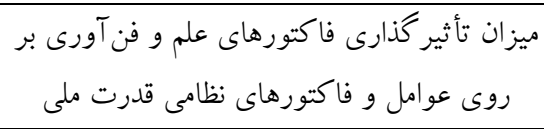 \\
\hline
\end{tabular}

نتايج بهدست آمده از بخش ميدانى يزوه هش، كواه بر اين ادعا است كه مؤلفههاى اقتصادى، نظامى، سياسى، فرهنكى، اجتماعى و

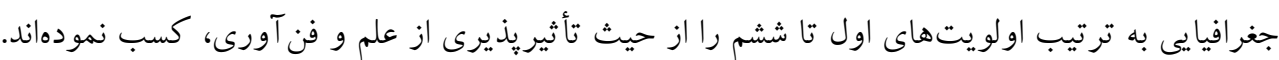

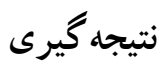

قدرت ملى داراى ابعاد و سرجشمههاى مختلف اقتصادى، اجتماعى، سرزمينى، فرهنكى، نظامى، علم و فن آورى و ... مىباشد.

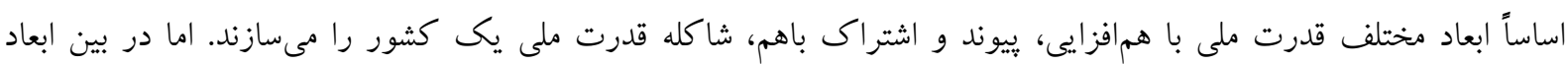

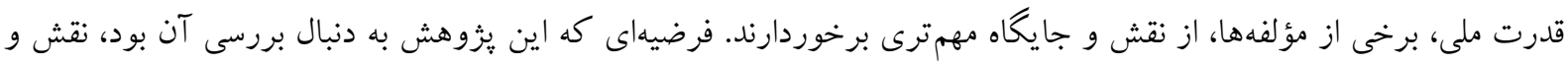

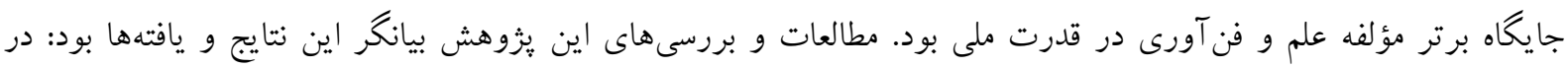




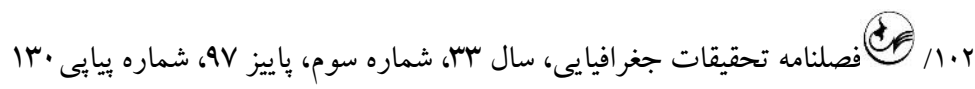
عرصه اقتصاد كه زيربناى ساير ابعاد قدرت است؛ مؤلفه علم و فن آورى موجب شكل گيرى مفاهيمى ازجمله اقتصاد دانشبنيان

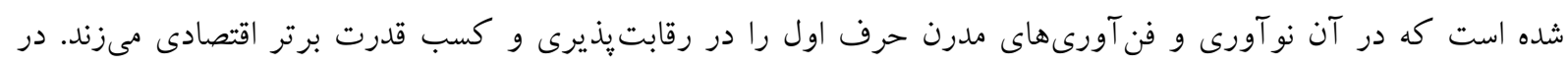
تقويت قدرت نظامى و دفاعى نيز علم و فن آورى نقش بسيار برجستهاى دارد و با خلق فن آورى هنا، تسليحات، تجهيزات

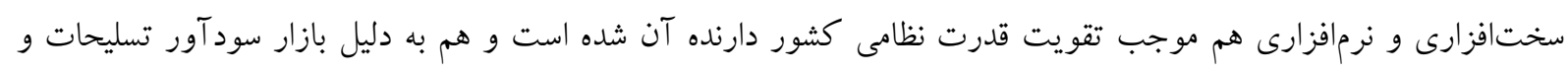

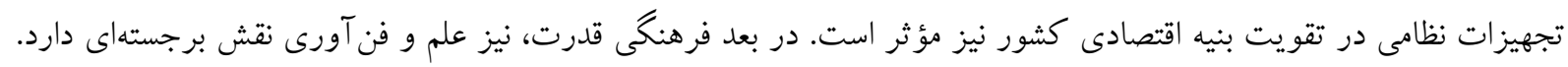

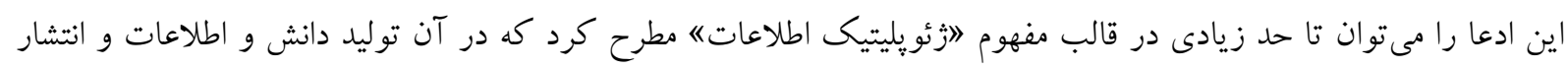

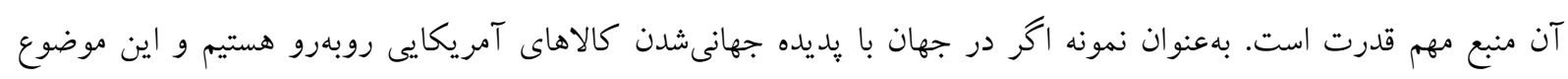

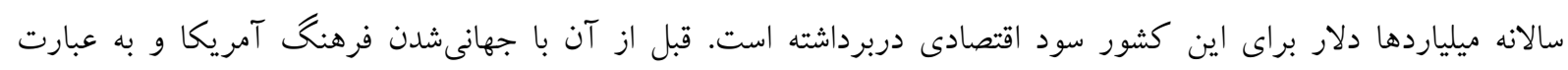

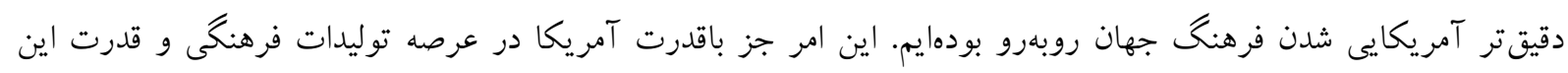

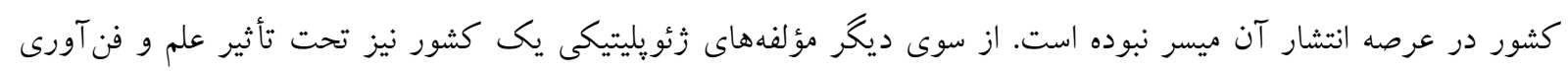

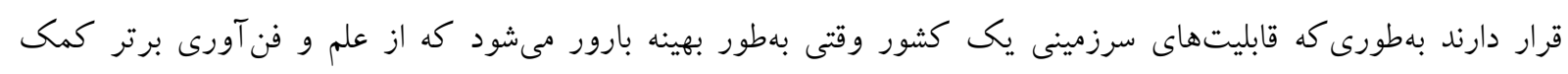

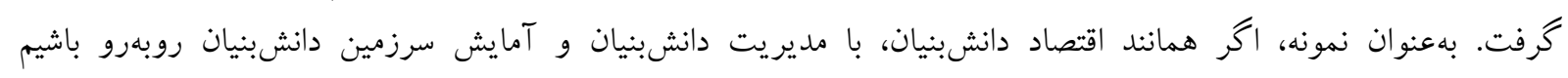

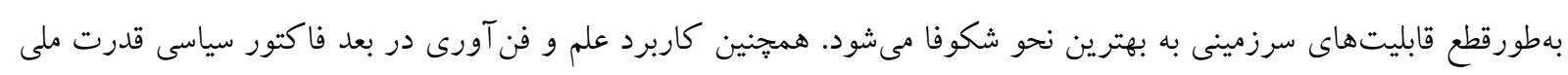

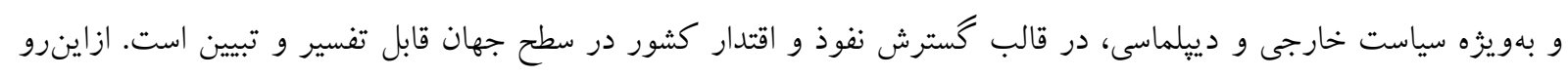

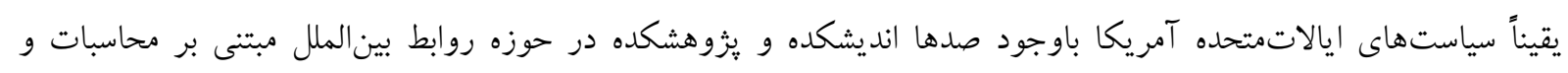

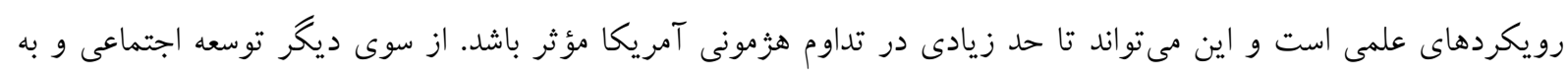

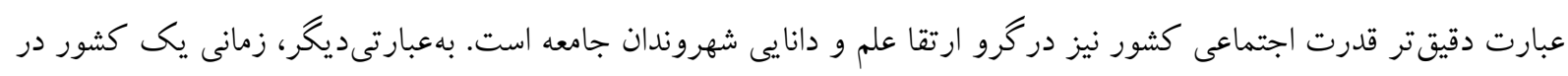

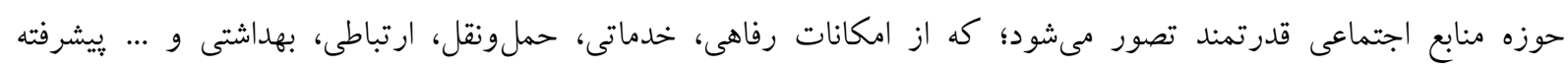

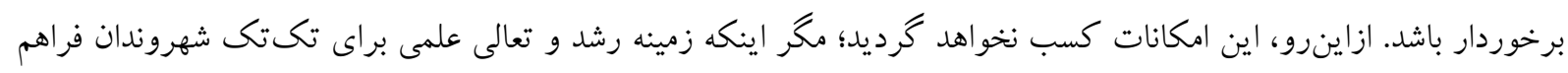

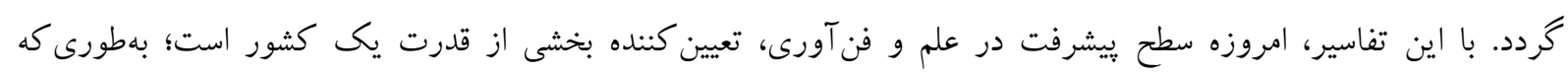

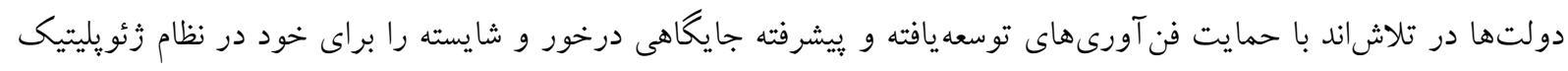

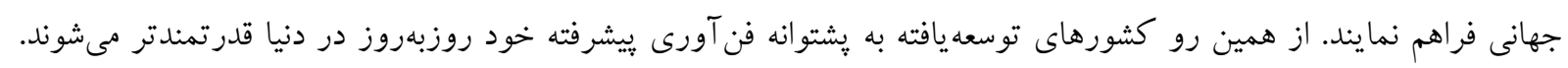

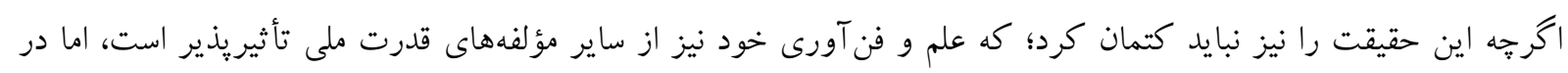

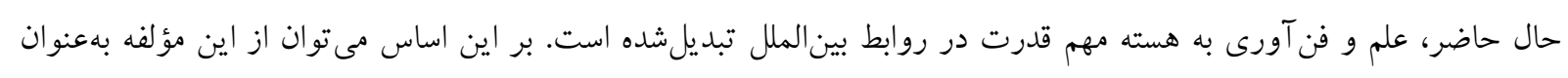
سنگ بناى قدرت ملى ياد كرد.

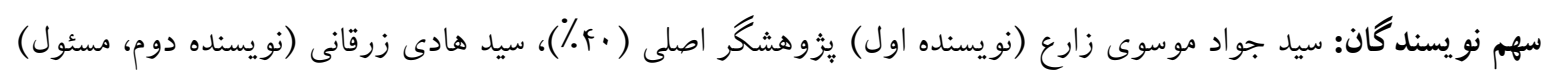

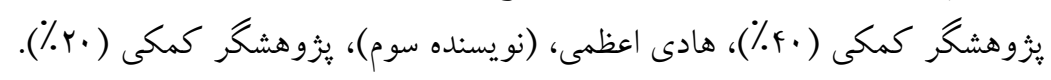

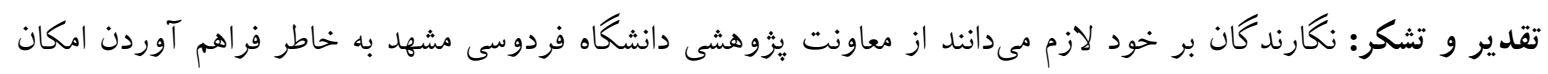
انجام يزوهش حاضر تشكر و قدردانى نمايند.

\section{منابع و مآخذ}

Ahmadi, A., \& Ghaffarian, W. (2003). Principles of cognition and research, method (with looking to historical studies). Quarterly of Human Sciences University of Al-Zahra, 13(46-47), 241-266. (Persian) 
Amjadi, K., Rahbari Banaeiyan, G. R., \& Soltani Fesghendis, G. R. (2012). Analysis the effect of knowledgebased economic indicators on the GDP of the countries. Journals of Productivity Management (Beyond Management), 6(21), 83-103. (Persian)

Asadi, S. (2013). The scientific wealth reflects the position of technology science and innovation in development. Monthly the Book of Month of Comprehensive, 16(10), 6-8. (Persian)

Bashiriyeh, H. (2000). Theories of culture in the twentieth century. Tehran: Cultural Institute of Pouyan Ayandeh. (Persian)

Bellany, I., \& Farhangh Kherad Mand, A. B. (1994). Science, technology and military power. Journal of Defence Policy, 5(5), 1-20. (Persian)

Davoodi, A. A. (2014). The Iranian science and technology diplomacy in afghanistan: challenges and opportunities. Journal of Strategic Research of Politics, 3(11), 103-127. (Persian)

Deh Moobed, B., Mehregan, N., \& Dehghan Poor, M. R. (2011). Exporting industries based on high-technology and factors affecting it's. Journal of Science and Technology Policy, 3(4), 69-82. [DOI:10.22034/jstp.2011.3.4.535148]. (Persian)

Dehghani Firoozabadi, S. J. (2015). Principles and fundamentals of international relations (1). Tehran: Samt. (Persian)

Dick, C. J. (2003). The future of conflict: looking out To 2020. Camberley: Defence Academy of the United Kingdom.

Esudu, S. (2016). National power and international relations. Munich: GRIN Verlag.

Ezzati, E. (2012). The geostrategy and the twenty-first century (Seventh ed.). Tehran: Samt. (Persian)

Faraji Rad, A. R., \& Abdi, M. (2015). Scienctific and technological development and its impact on the rising of regional power (comparative study: I.R.I and India). Quarterly of Geopolitics, 11(3), 59-83. (Persian)

Gilpin, R. (2013). Global political economy: understanding the international economic order (M. Mir Mohammadi, M. Yazdan Fam, A. R. Khosravi, \& J. M, Trans.). Tehran: Tadbir Institute of Economic Research. (Persian)

Hafez Nia, M. R. (2011). Principles and concepts of geopolitics. Mashhad: Papoli. (Persian)

Haj Fathaliha, A. (1993). Technology development. Tehran: Allameh Tabatabai University Press. (Persian)

Heydari, G. R. (2010). Scientometrics: or the concept of science in scientometrics. Monthly the Book of Month of Comprehensive, 13(10), 72-77. (Persian)

Hohn, K. H. (2011). Geopolitics and the measurement of national power. (PhD dissertation), University of Hamburg.

Iran Technology Analysts Network. (2011). Conceptual survey of science and technology diplomacy and its current status in the Islamic Republic of Iran. Tehran: Vice-presidency For Science and Technology. (Persian)

Jablonsky, D. (1997). National power. US Army War College Quarterly, 27(1), 34-54.

Jamshidi, M. H. (1995). Analysis and survey of elements of military power. Journal of Military Analyzes (Journal of Strategic Studies of Basij), (23-24), (Persian)

Kazemi, A. A. (2008). International relations in the theory and action (Fifth ed.). Tehran: Ghoomes. (Persian)

King, A., \& Larijani, F. (1996). Science and technology evolution after world war II. Rahyaft Journal, 6(13), 2939. [DOI:10.22034/Rahyaft.1996.6.13.538253]. (Persian)

Kluz, A., \& Firlej, M. (2015). The impact of technology on foreign affairs: five challenges. Retrieved from https://foreignpolicyblogs.com/2015/12/22/the-impact-of-technology-on-foreign-affairs-fivechallenges/

Lall, S. (2000). Export Performance and Competitiveness in the Philippines. QEH Working Paper, Queen Elizabeth House, University of Oxford. Retrieved from www.3.qeh.ox.ac.uk/pdf/qehwp/qehwps49.pdf

Mahmoud zadeh, E., Ghazi, H., \& Ghouchani, M. M. (2017). The role and position of technology development in the military dimension of national power. Quarterly of Strategic Defense Studies, 15(67), 261-284. (Persian)

Mallik, A. (2016). Role of technology in international affairs. New Delhi: Pentagon Press.

Mirzaei, S., \& Abdi, M. (2003). Technology, concept \& policie. Paper presented at the The Second Conference on the Future of Science and Technology and Strategies, Tehran Center for Strategic Research (CSR). (Persian)

Modares, M. V., Khalili, R., \& Ata Negad, H. (2017). The role of military-industrial complexes in us foreign policy. International Relations Research Quarterly, 7(24), 185-214. (Persian) 


$$
\text { Ir ·.F }
$$

Mousavi Zare, S. J. (2017). The review and analysis of effective variables on the power of science and technology and its role in national power of countries. (Master's thesis), Ferdowsi University of Mashhad. (Persian)

National Research Council. (1999). The pervasive role of science, technology, and health in foreign policy: Imperatives for the department of state. Washington, DC: The National Academies Press.

National Research Council. (2009). 21st century innovation systems for Japan and the United States: Lessons from a decade of change: Report of a symposium. Washington, DC: The National Academies Press.

Nazari Zadeh, F., Mehdi Nejad Nouri, M., \& Hejazi, S. R. (2014). The role of individual factors in the success of innovations in Iran's defense industry. Journal of Improved Management, 7(22), 128-133. (Persian)

Noroozi Chakoli, A. R. (2012). The role and situation of the scientometrics in development. Journal of Information Processing and Management, 27(3), 723-736. (Persian)

Noroozi Chakoli, A. R., Hasan Zadeh, M., \& Noor Mohammadi, H. A. (2009). Assessment of science, technology and innovation (concepts and international indicators). Tehran: Science Policy Research Center. (Persian)

Nye, J. (2008). Power in the global information age: from realism to globalization (S. Mir Torabi, Trans.). Tehran: Research Institute of Strategic Studie. (Persian)

Nye, J. (2010). Soft power: the means to success in world politics (S. M. Zolfaghari \& M. Rouhani, Trans.). Tehran: Imam Sadiq University Press. (Persian)

OECD. (1996). The knowledge-based economy. Paris: OECD Press.

OECD. (2002). Science, technology and industry outlook. Paris: OECD Press.

Oxford University. (1997). Oxford dictionary. United Kingdom: Oxford University Press.

Partov, A. (2015). The crisis in ukraine and the collapse of joint military projects between russia and the west. The institute for Iran-Eurasia studies. Retrieved from http://www.iras.ir/fa/doc/note/672. (Persian)

Pillsbury, M. (2000). China debates the future security environment. Washington, DC: National Defense University Press.

Quartz News Website. (2013). Why israel dominates global drone exports. Retrieved from https://qz.com/102200/why-israel-dominates-global-drone-exports/

RT News Website. (2014). All countries will have drone kill technology in 10 years - Report. Retrieved from www.rt.com/news/157340-us-drones-military-defense/

Sadeghi, M., \& Azarbayejani, K. (2006). Knowledge based economy and demand for labour in Iran. Iranian Journal of Economic Research, 8(27), 175-197. (Persian)

Schiller, H. (1997). Mass communications and american empire (A. Abedini, Trans.). Tehran: Sourosh Publications. (Persian)

SciDev News Website. (2009). Obama vows to boost science ties with muslim world. Retrieved from www.scidev.net/global/capacity-building/news/obama-vows-to-boost-science-ties-with-muslimworld.html

Seyoum, B. (2004). The role of factor conditions in high-technology exports: An empirical examination. The journal of high technology management research, 15(1), 145-162. [DOI:10.1016/j.hitech.2003.09.007]

Shahnazi, R. (2013). Factors affecting production on technology industries of high-technology in the knowkedge-based economic (Panel Data Approachbygls). Quarterly of Roshd-e-Fanavari, 9(33), 2-12. (Persian)

Smith, R. H., El-Anis, I., \& Farrands, C. (2013). International political economy in the 21st century: contemporary issues and analyses (A. M. Haji-Yousefi \& R. Talebi Arani, Trans.). Tehran: Mokhatab. (Persian)

Stockholm International Peace Research Institute. (2018). Trends in international arms transfers, 2017. Retrieved from https://www.sipri.org/sites/default/files/2018-03/fssipri_at2017_0.pdf

Taleghani, G. R. (2005). The role of technology management in sustainable development. Journal of Peyke Nor, 3(3), 34-41. (Persian)

The guardian News Website. (2006). Pentagon's new weapon - cyborg flies that are spies. Retrieved from https://www.theguardian.com/technology/2006/mar/15/news.usnews

The guardian News Website. (2015). The numbers behind the worldwide trade in drones. Retrieved from www.theguardian.com/news/datablog/2015/mar/16/numbers-behind-worldwide-trade-in-drones-ukisrael 
Turekian, V. (2016). The role of science diplomacy in international crises; syria as a case study. Retrieved from https://2009-2017.state.gov/e/stas/2016/260459.htm

Valavi, M. R., Tarhani, F., \& Mojaradi, S. (2011). Extraction of science and technology priorities in the field of defense, national security and foreign policy. Quarterly of Defense Strategy, 10(36), 27-64. (Persian)

Weiss, C. (2005). Science, technology and international relations. Technology in Society, 27(3), 295-313. [DOI:10.1016/j.techsoc.2005.04.004]

Zahedi, S. S., \& Kheirandish, M. (2007). Explaining structural factors in knowledge based economy: a case study. Iranian Journal of Management Sciences, 2(6), 49-68. (Persian) 